the solution is equal to 0.1346 gram of the dry salt, and this equivalent has been used in the experiments cited.

The writer trusts that these results may help to solve the difficult question of errors due to the volume of precipitate and offers the above method as one which at least will go a long way toward arriving at correct results in optical sugar analysis.

\title{
REVIEWS.
}

\section{Some Abstracts from the Recent Literature of Industrial Chemistry.}

BY FRANK H. THORI.

PROGRESS in the various chemical manufacturing lines is more or less correctly indicated by the number and character of the investigations published, and future changes are often foreshadowed thus. The abstracts in the Review of American Chemical Research contain a summary of recent chemical work in this country. In the following article it has been lesired to bring together certain of the more important contributions to the literature of industrial chemistry, with especial reference to those appearing in foreign journals.

To give exhaustive reviews, or even to enumerate all the material bearing upon the technical applications of chemistry, published within the last year or two, would far exceed the limits of this article, and if anything of value has been omitted, the limits of time and space and the liability to overlook something in so hasty a survey, must be the reasons given. Articles of a purely theoretical character, where immediate practical applications are not obvious, and those relating to analytical and organic processes, having but a remote connection with industrial requirements, have generally been passed over, but some attempt has been made to select material from a few of what appear to be the most important of the many patents recently issued.

Technical Education.-The subject of education in technical branches, including chemistry and chemical engineering, continues to receive much attention both in this country and abroad. The English Parliament last year passed an Educational Bill, which, however, does not appear to meet the ideas of those who are working for a higher grade of secondary education. Defects in the bill are pointed ont by Mr. Levinstein in his presidential address to the Society of Chemical Industry, at Bradford. He shows that the efforts now being made in England to increase the number of technical schools, are in a large measure, misdirected energy, and he says very truly, that what the country needs is 
a much larger number of highly trained men of science, but these cannot be obtained unless the buys are provided with suitable instruction in general knowledge before attempting special education. Much benefit is expected to accrue from the opening of a special department in the Manchester school, to teach the textile arts. But the difficulty is to find enough pupils with the proper preparatory training. One or two such schools may be able to accommodate all the young men available.

Miscellaneous.-Bertin, in a paper on the alumino-thermal process of Goldschmidt, sums up the advantages of the process: The metals and alloys made are free from carbon or other impurities; temperatures as high as those attained by electricity may be had by suitable choice of oxides and without cumbersome apparatus; the heat of the reaction can be exactly calculated beforehand, since it is dependent upon the quantity and kind of "thermit" mixture employed. Calcium carbide may be readily made by this process, without electrical heating (Mem. Soc. des Ing. Civils de France, 1902, pp. 218-249). Sadtler (J. Soc. Chem. Ind., I903, p. 193) reviews the materials used in fire-proofing wood, and the points to be attained in practical working, especially with reference to the Ferrell method. The author concludes that the wood is five times as resistant to flame as any previously produced, while no injury to the structural strength results. Vignon (Bul. Soc. Chim., 29, 515 (1903)) finds that a trace of copper greatly assists the reduction of ammoniacal silver nitrate by a tartrate, in silvering glass, and the temperature is lowered. More than a trace of copper present retards the process and injures the color of the mirror. Dunstan (Proc. Chem. Soc., I9, I50) found that the chemical reactions taking place in the rusting of iron are:

$$
\begin{gathered}
\mathrm{Fe}+\mathrm{O}_{2}+\mathrm{H}_{2} \mathrm{O}=\mathrm{FeO}+\mathrm{H}_{2} \mathrm{O}_{2} . \\
2 \mathrm{FeO}+\mathrm{H}_{2} \mathrm{O}_{2}=\mathrm{Fe}_{2} \mathrm{O}_{2}(\mathrm{OH})_{2} .
\end{gathered}
$$

The water must be present as liquid; no rusting takes place if the temperature be kept so high that the water-vapor does not condense. The presence of salts, which decompose hydrogen peroxide, was found to prevent the rusting of iron, and it is concluded that hydrogen peroxide is an important factor in the rusting; metals which are oxidized by the peroxide will rust in the air, while metals which it does not attack are not rusted in the air. It is held that carbon dioxide is not essential to rusting, but undoubtedly assists the process, if present; aqueous carbonic acid reacts on iron to liberate hydrogen and form ferrous carbonate and bicarbonate; if oxygen is present, these carbonates are oxidized to produce rust which contains some carbonate. Moody (Ibid., p. I 57) holds the retarding action of certain salts to be due to their prevention of the absorption of carbon dioxide by the 
solution. The author considers the attack of the acid on the iron as the first action in rusting, followed by oxidation of the ferrous salt. Whitney (This Journal, 25, 394) considers the corrosion of iron to be an electro-chemical process. It is dependent in the first instance only upon the concentration of hydrogen ions in the liquid. Alkalies diminish this concentration by producing hydroxyl ions and thus hinder corrosion. Carbon dioxide is not essential, but may be very important as a factor in corrosion, since it may be driven out on boiling, to redissolve in the cooler parts of the apparatus; this solution then may further dissolve iron:

$$
\mathrm{Fe}+2 \mathrm{CO}_{2}+2 \mathrm{H}_{2} \mathrm{O}=\mathrm{FeH}_{2}\left(\mathrm{CO}_{3}\right)_{2}+\mathrm{H}_{2} \text {. }
$$

On boiling, the dissolved bicarbonate of iron precipitates ferric hydroxide and the carbon dioxide is liberated to again pass into cooler parts of the apparatus, to again attack the iron, and the cycle is repeated. Muir, Schenk and Marquart (Ibid.. p. 1225) have produced a new chemically active variety of red phosphorus by boiling a Io per cent. solution of white phosphorus in phosphorus tribromide. The product, a scarlet powder, is suitable for friction-match heads to light on any surface; it is non-poisonous and has no action on glue or gelatin used as cementing material. Its ignition point is $170^{\circ} \mathrm{C}$. Davies (J. Soc. Chem. Ind., Igo3, p. 199) has published data and tests relative to the efficiency of different heat insulating materials; magnesia, hair felt and ground cork, are good insulators. Kieselguhr is good, but heavy, while slag wool is variable and should be tested. Sawdust is poor, but cheap, and asbestos is not suited for many purposes.

\section{METALLURGY.}

Aluminum.-Improvements in this industry appear to be, for the most part, in the direction of purification of the crude materials before reduction. Also, better quality of anodes are used in the furnaces than formerly. Improved methods of soldering and welding the metal have been devised (Peters: Berg. u. hüttenm. Ztg., I902, p. 445). Campbell and Mathews (This Journal, $24,253-266$ ) have studied the alloys of aluminum with lead, bismuth, copper, cadmium, platinum, nickel, tin, antimony and tungsten. The effect of exposure to the atmosphere of London on certain aluminum alloys has been investigated and the results tabulated by Wilson (Electrician, 1902, p. 868; 1903, p. 898).

Lead.-Salom (Trans. Am. Electrochem. Soc., I902, p. 87) describes the process of the Electrical Lead Reduction Co. at Niagara Falls, for producing spongy lead direct from galena, by a wet reduction process. The sponge is used for litharge and for storage batteries. Schnabel reviews various propositions for lead 
reduction in Chem. Ztg., I903, p. I35. Clamer (J. Frank. Inst., I46, 49 (I903)) has made an elaborate study of the alloys intended for bearings. The addition of lead to white metal and bronzes, increases the resistance to wear, of the alloys, but also increases the friction to a small degree.

Cadmium.-Boudouard has published results of an investigation upon the alloys of cadmium and magnesium, in Compt. rend., I34, I43I-I434. Gautier has studied the alloys of barium and calcium with cadmium (Compt. rend., I34, I054-I056).

Copper.-Siemens and Halske (Chem. Centrbl., I 902, I, 900) propose to obtain copper, nickel and magnesium from ores containing these metals with iron, as oxides, carbonates or silicates, by heating to $500^{\circ}$ to $1000^{\circ} \mathrm{C}$., while stirring constantly and passing over the mass a heated mixture of air and sulphur dioxide. By lixiviation, the sulphates of these metals are obtained, but the iron for the most part remains in the residue. Thofehrn and St. Seine (Berg. u. hüttenm. Ztg., 64, 943 (Ig03)) concentrate copper, nickel matte and black copper by fusion in a reverberatory and blow in air, super-heated steam and sand; the various impurities are oxidized and slagged off. Beadle reviews electrolytic copper processes in the Electr. Review, 5I, 546 (I902). He considers the electrolysis in fused electrolytes as of little promise. Neill, in Eng. Min. J., I90I, May 30, proposes to extract copper from such ores as contain carbonate or oxide, by the use of sulphur dioxide. The process labors under disadvantages, as shown by Schnabel.

Nickel.-Mond's process of forming nickel carbonyl from the ore, and decomposing the gas by heating, to set free carbon monoxide and metallic nickel, is stated to be in operation in a works in Wales. The ores of Sudbury, Canada, are smelted to form a copper-nickel matte, which is sent to the Welsh plant (Min. Ind., I902, p. 26I). Later a strange sickness among the workmen has caused partial suspension of the work (Min. Ind., I903, p. 233). The Browne process (U. S. Pat. 7I4,86I (I902)) for the separation of copper and nickel is described in Electrochem. Ind., I903, pp. 38I and 569. The reactions given are:

$$
\begin{aligned}
& 2 \mathrm{CuNi}^{2}+6 \mathrm{Cl}=\mathrm{Cu}_{2} \mathrm{Cl}_{2}+2 \mathrm{NiCl}_{2} \\
& \mathrm{NiCl}_{2}+\mathrm{FeCl}_{3}+3 \mathrm{NaOH}=\mathrm{NiCl}_{2}+3 \mathrm{NaCl}+\mathrm{Fe}(\mathrm{OH})_{3} \\
& \mathrm{NiCl}_{2}+\text { current }=\mathrm{Ni}+2 \mathrm{Cl}
\end{aligned}
$$

Chlorine is passed into a tower filled with copper-nickel matte, while salt brine flows down the tower. The solution of cuprous and nickel chlorides is electrolyzed, with a copper-nickel anode and a copper cathode; copper is deposited on the cathode and the chlorine dissolves the anode of copper-nickel. Thus the con- 
centration of the nickel in the solution increases; after chemical purification of the solution, the nickel is also deposited on a nickel cathode. Perron proposes to extract nickel from its finely powdered ores by means of ammonium sulphide solution (German patent No. I 37,006). The Frasch extraction process, using ammoniacal brine to precipitate nickel-ammonium chloride, with caustic soda as a by-product, is reported not successful in Ontario (Min. Ind., I903, p. 232). Ulke separates nickel electrolytically from its copper alloy, which is obtained from a copper-nickel matte (Min. Ind., I902, p. 497). Comments upon the recent advances in the metallurgy of nickel are made by Dürre in Chem. Ztschr., 2, 83, I I 4, I 37, I69. Moissan finds that nickel is oxidized by the action of fused lime (Compt. rend., I 34, I 36- I 42). Boudoulard, in a study of the reducing action of charcoal, finds nickel oxide easily reduced, but less easily than copper oxide ( $\mathrm{Ann}$. chim. phys., 24, 77). Vahlen finds that the toxic action of nickel carbonyl on animals is peculiar, and materially different from that of carbon monoxide. He holds the idea that the nickel compound itself exerts a specific toxic action and by later decomposition, yields carbon monoxide to which the poisonous action has been attributed (Chem. Centrbl., I902, II, 463). Coehn describes nickel-magnesium alloys obtained by electrolysis ( $Z$ tschr. $f$. Elektrochem., 8, 59I-595). Wunsche reports on the magnetic properties of nickel amalgam (Berw. u. hiittenm. Ztg., IgO2, p. 430). Dixon, having analyzed samples of the Sudbury ore, has come to the conclusion that the nickel is present chiefly as pentlandite, (NiFe)S (Eng. IFin. J., 1902).

Platinum.-Rainer reports on the platinum industry in the Ural regions; the economic limits of platinum for profitable working ranges from 0.25 to 1.10 grams per ton in various cases (Berg. u. hüttenm. Ztg., Ig02, p. 307). Hartley has studied the cause of brittleness in platinum by examining the spectrum of an electric spark between poles of such brittle platinum. $\mathrm{He}$ concludes that the brittleness and crystalline structure may be caused by minute quantities of phosphorus and carbon, which could scarcely be detected with the spectroscope (Phil. Mag., 4, (6), 84-89). Rosenhain has made a microscopic examination of the surface markings on platinum that has been ignited. They showed the appearance of an etched crystalline metal. By heating new metal in an oxidizing flame, similar crystalline appearances resulted, showing the effect not to be due to carbon from the flame (Chem. News, 1902, Aug. I). Winkelmann has studied the diffusion of hydrogen through platinum, and concludes that the diffusion through incandescent platinum is not proportional to the gas pressure (Ann. d. Phy's., 8, 388 (I902)). The disintegration of metals of the platinum group was the subject of 
an investigation by Holborn and Henning. Thin strips of foil, made from various metals and from alloys of them with platinum, were heated to incandescence by the electric current. After one or more hours heating, only slight loss of weight resulted with most of these metals, but iridium and its alloys showed marked loss through dusting. Associated with this, a loss of efficiency, amounting to several per cent., was shown by the thermo elements having such junctions (Sitzungsber. Kgl. Pr. Akad. Wiss. Berlin, I902, p. 936). Holborn and Austin (Sitzungsber. Kgl. Pr. Akad. Wiss. Berlin, 1903, pp. 245-248) have studied the disintegration of the platinum metals when electrically heated in various gasesair, oxygen, hydrogen, nitrogen-at different pressures, for thirty minutes. The heat was measured by an optical pyrometer. Platinum and rhodium, at atmospheric pressure, disintegrate five times faster in oxygen than in air; at $25 \mathrm{~mm}$. pressure, the rate is nearly one-half that at atmospheric pressure. Iridium in air, at atmospheric pressure, disintegrates ten times faster than platinum. Göttig (Ztschr. angew. Chem., IgO3, p. 4I 7 ) has invented gold solutions designed to plate base metals directly by reduction, after the painting on of the solution. Sulphur compounds of gold, which contain no oxygen, are dissolved in water, to which certain organic alcohols are added, to aid the stability of the solution. Gold chloride solution is treated with sodium sulphide, potassium thiocyanate, etc.; the addition of alcohol and oxalic acid and other substances affects the color of the deposit. The concentration of the solution varies with the conditions of the work; it must be greater for painting than for simple immersion in the bath.

Silver.-Bradford has studied the reactions of the Ziervogel process and makes a valuable contribution to its literature (Trans. Am. Inst. Min. Eng., I902). Holborn and Day, in a study of the melting-point of silver, found values of $953.6^{\circ}, 954.9^{\circ}$ and $961: 5^{\circ}$ by three separate methods. The high figure was obtained by fusing in vacuum; the absorption of oxygen by the melted metal when in the air, is given as the cause of the lower values. Other trials with the air-thermometer, platinum resistance and optical methods, gave $955^{\circ}, 955^{\circ}$ and $962^{\circ}$. Spurting occurred after solidification, between $933^{\circ}$ and $940^{\circ}$, averaging $936^{\circ}$. Attempts to saturate the fused metal with oxygen, and thus find a fixed melting-point, were failures. A lowering of the solidification-point to $93^{\circ}, 939^{\circ}$ and $942^{\circ}$, was noticed (Ann.d. Phys., 2, 527 (I900)).

Zinc.-Borchers proposes to chlorinate certain zinc ores in the presence of water, lixiviate and electrolyze the dehydrated chlorides to obtain the zinc ( $Z$ tschr. angew. Chem., 26, 637-642). The proposal to reduce zinc oxide under 2 to 3 atmospheres' 
pressure, advocated by Lungnitz (Chem. Ztg., Igo3, p. 136) and Schulphaus (J. Soc. Chem. Ind., Igo3) has not yet, apparently, been put in practice. The loss of silver in roasting zinc blende is found by Sander to amount to Io to I 2 per cent. of the total silver in the ore (Ztschr, angewu. Chem., I902, 353). He found the loss of lead in other experiments amounted to 7.88 to 21.8 per cent. (Berg. w. hiuttenm. Ztgr., 1902, p. 56r). Frost and Lecocq found the fluorine loss in roasting blende to range from 3 I to IOO per cent. of the total amount in the ore (Chem. Centrbl., Ig02, II, I62-I63). The use of sulphur dioxide from blende roasting, for sulphuric acid, by the contact process is, according to Schnabel, being introduced in several zinc works (Chcm. Ztg., I903, p. I 37). Boudouard finds that at II $25^{\circ}$ to 1 I $50^{\circ}$ the action of charcoal on zinc oxide yields a regular fow of gas, containing, on an average, 99 per cent. carbon monoxide and I per cent. carbon dioxide, by volume (Amn. chim. phys., 24, 74). Lewis has studied the micro-structure of zinc with small, determined impurities (Chem. Now's, 86, 2II). Sander has experimented with zinc blende containing barytes; he concludes that the presence of barytes does not cause a retention of zinc in the residues in the retort (Berg. w. hiittenm. Ztg.. T902, p. 465). Friedrich (Ztschr. angerv. Chem., I903, p. 269) carried on experiments with alloys of gold and zinc, with a view to studying the volatility of the gold; tabulated results of fifteen experiments are given; the loss of gold by vaporizing is very small, and the author considers it to be a mechanical loss, due to very rapid volatilization of the zinc. Féry (Am. chim. phys., 28, 428) determined the boiling-point of zinc to be I $140^{\circ} \mathrm{C}$, and of copper to be $2100^{\circ} \mathrm{C}$., when heated in an electric furnace. The two metals in brass could be separated readily by fractional distillation.

Iron and Steel.-W. A. Bone ( $J$. Soc. Chem. Ind., 1903, p. I81) reviews at length the recent developments in the iron and steel industries, considered from an economic standpoint. Guillet (Comp. rend., 136,227 ) has studied the micrography of nickel steels, containing $0.120,0.35^{\circ}$ and 0.850 per cent. carbon, respectively, and the nickel ranging from o to 30 per cent. An alcoholic picric acid solution was used for etching; in each series, as the nickel increased, the pearlite crystals were gradually replaced by martensite, which in turn gave way to the polyhedra of $\gamma$-iron; in high carbon steel a small percentage of nickel caused the changes. Allen (Engineer, 96, 84 (1903)) has constructed a chart of the reactions and temperatures in the blast furnace. Charpy (Compt. rend., I37, I2O (1903)) shows the action of carbon monoxide on iron at temperatures ranging from $560^{\circ} \mathrm{C}$. to II $90^{\circ} \mathrm{C}$ : : up to $750^{\circ} \mathrm{C}$. carbon deposits on the iron and no carbon dioxide is formed; above this temperature the speed of 
cementation increases to a maximum, at $900^{\circ} \mathrm{C}$, and then does not materially increase, but saturation is not reached. Ferric oxide, heated in carbon monoxide, is reduced between $200^{\circ}$ and $\mathrm{I} 200^{\circ} \mathrm{C}$., but the iron is more or less carburized.

\section{ELECTRIC FURNACE AND HEATING.}

Dr. H. Goldschmidt in Section X, Int. Congress for App'd Chem., Berlin, gave a paper on the manufacture of iron and steel in the electric furnace. The various processes were tabulated, with data as to the furnace type, raw material (charge), horse-powerhours per ton of product and costs. The manufacture of tool steel by the electric method is carried on profitably by several processes, notably those of Heroult and Kjellin. Heroult's steel shows the following composition:

Per cent.

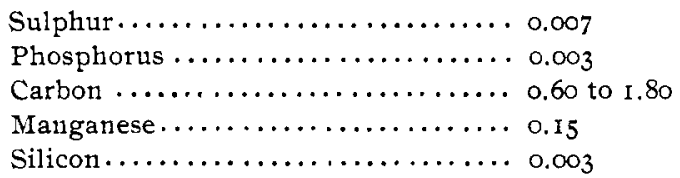

The Kjellin steel shows in three samples:

\begin{tabular}{|c|c|c|c|}
\hline & $\begin{array}{c}\text { I. } \\
\text { Per cent. }\end{array}$ & $\begin{array}{l}\text { II. } \\
\text { Per cent. }\end{array}$ & $\begin{array}{l}\text { III. } \\
\text { Per cent. }\end{array}$ \\
\hline 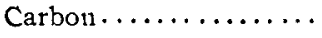 & . I.45 & 1.20 & 0.95 \\
\hline Silicon $\ldots \ldots \ldots \ldots$ & . 0.47 & 0.74 & 0.35 \\
\hline Manganese...$\ldots \ldots \ldots$ & . 0.49 & 0.46 & 0.33 \\
\hline Phosphorus .......... & . $0.01 \mathrm{I}$ & 0.013 & 0.014 \\
\hline Sulphur..$\ldots \ldots \ldots \ldots$. & . 0.010 & 0.010 & 0.015 \\
\hline
\end{tabular}

This method is capable of working with large charges, even as much as I ton of metal, while the cost of the furnace itself is not excessive. Mr. Ruthenburg, in a paper before the fourth general meeting of the American Electrochemical Society, at Niagara Falls, states that his process is especially adapted to making steel from iron ores containing sulphur and phosphorus in high per cent. The ore must be crushed, passed through a magnetic concentrator and smelted in the electric furnace. He claims that the action of the current in his furnace is merely to agglomerate the ore dust and heat the material for the next stage of the process, the reduction of the ore by hot carbon monoxide in the soaking pit. The power necessary to agglomerate and heat the charge is said to be $250 \mathrm{kw}$.hours for a ton of ore; the size of the agglomerated mass is important and is said to be readily controlled; the reduction is complete. The phosphorus is eliminated by the magnetic separator; the sulphur is removed by the reaction between the $\mathrm{Fe}_{3} \mathrm{O}_{4}$ and $\mathrm{FeS}_{2}$ at the high temperature of the agglomerating process. Reduction of the ore by carbon monoxide requires only a low heat in the soaking pit. It is expected that the process 
will be put upon an industrial basis soon. Heroult has published a description of his electric steel process (Electro-chemical Industry, I, 449 (1903)) and states that with scrap iron, either mixed with pig or not, he can now produce the finest quality of tool steel, equal to any crucible steel. A daily production of 150 tons is expected in the near future. Neumann (Ztschr. Elektrochem., 1902, p. 939) claims that during the reduction of metals by calcium carbide the reaction produces carbon monoxide chiefly. Bradley, Read and Jacobs (U. S. Patent $7 \mathrm{I} 6,182$ ) have produced carbophosphide of calcium by heating in an electric furnace a mixture of quick-lime, calcium phosphate and carbon: $2 \mathrm{CaO}+\mathrm{Ca}_{3}\left(\mathrm{PO}_{4}\right)_{2}+\mathrm{I} 6 \mathrm{C}=\mathrm{Ca}_{5} \mathrm{C}_{6} \mathrm{P}_{2}+$ IOCO.

The substance decomposes with water to form a mixture of phosphine and acetylene, which inflames spontaneously. A new product of the electric furnace is siloxicon, to which the formula $\mathrm{Si}_{2} \mathrm{C}_{2} \mathrm{O}$ is assigned, though samples show some variations from this. It is of grayish green color, is tneffected by acids, except hydrofluoric, and is very refractory, heing well adapted to furnace linings, crucibles, muffles, etc. In the presence of an excess of oxygen at high temperatures the material decomposes into silica and carbon dioxide. It is made by heating a charge of sand and coke, with some saw-dust to give porosity.

Lethenle (Electrochem. Ind., 1903, p. 573) states that sodium is obtained in France by the Becker process, using a fused electrolyte of caustic soda and carbonate of soda; the estimated cost for a large plant, to produce $180,000 \mathrm{~kg}$., using 500 horse-power at \$IO per horse-power-year, is 23.6 cents per kilo. This furnace is also used to reduce mixtures of chromates, aluminates or tungstates of sodium: alloys, such as chromiumaluminum, are obtained and sodium distils off.

Carbides.-Moissan (Compt. rend., I 36, 1522-I 525 (1903)) has examined the reaction between the hydrides of calcium, potassium, rubidium and caesium at $100^{\circ} \mathrm{C}$., and acetylene gas, whereby acetylene-acetylides of the metal are formed. In vacuo, these dissociate on heating, acetylene gas escaping and the metallic carbide remains; thus the carbides may be formed at comparatively low temperatures. Moissan and Kouznetzow (Ibid., 137, 292 (1903) ) have prepared a double carbide of chromium and tungsten, having the composition $\mathrm{W}_{2} \mathrm{C} \cdot \mathrm{Cr}_{3} \mathrm{C}_{2}$. The compound is a hard, stable substance and is suggested as of possible use in making chrome steel.

Electrochemistry.-Kershaw (Lond. Electrical Review', I903, Sept. I8) has examined the corrosion of aluminum when exposed to the weather, and tabulated the results. He found that all of the samples showed corrosion after a year's exposure, and 
he does not consider aluminum as yet proved to be better than copper for exposed electrical conductors. A report ( $Z$ tschr. $f$. Carbidfabrikation, Ig03, Sept.) by a government commission upon the use of acetylene for illumination in mines, concludes that acetylene lamps cannot yet be safely put into the hands of ordinary miners. Schoop (Electrochem. Ztschr., I903, Sept., p. I 3I) discusses industrial electrolysis of water by the methods of Schmidt, Garuti and himself; the electrolyte in the first two methods is an alkali, in the last an acid. The apparatus of each is described and data relating to the working of the Schoop apparatus and a summary of the industrial uses of the gases are included. Walker (Electrochem. Ind., I903, p. 579) describes the SiemensSchuckert apparatus for the commercial production of hydrogen and oxygen from the electrolysis of water; the electrolyte is a 20 per cent. caustic potash solution, distilled water being added as needed to keep the concentration constant. The temperature of most economical working is $7 \mathrm{O}^{\circ} \mathrm{C}$.; the production is about I 50 liters of hydrogen and 75 liters of oxygen per kw.-hour. The process is working successfully in Germany. Becker (L'Industrie Electrochimique, I903, Sept.) describes the advantages of the electric furnace for obtaining mercury from its ores. By heating the ore with lime, the mercury is all distilled off readily and the process can be made continuous. The Gerard process for the production of metallic powders, by heating in the electric furnace, is described in the same issue. The metal is vaporized in the presence of an inert gas, and the vapor condensed in a chamber filled with the same inert gas. By admitting air to the furnace and condensing room, oxides of the metals are formed. The electrolytic production of lead salts is described by Elbs and Nueblin (Ztschr. Elektrochem., Sept. I7, 1903). The study of the production of lead chloride is given in some detail.

Electrolysis.-F, Foerster, in a paper presented to Section X, International Congress for Applied Chemistry, at Berlin, drew attention to electrolysis as used in preparing various inorganic substances. Among others, may be mentioned ceric sulphate, $\mathrm{Ce}\left(\mathrm{SO}_{4}\right)_{2}$, which can be prepared Irom cerous sulphate in this way. Ceric sulphate has powerful oxidizing properties, resembling the permanganates in this respect, and would seem to offer great usefulness in situations where it can thus be regenerated readily from the cerous salt by electrolysis. Streintz (Chem. Centrbl., I902, II, I493) in studying the conductivity of metallic oxides and sulphides, found that light- and brilliant-colored powders are not electrical conductors, while dark-colored powders are also partly non-conductors; but of these latter, those that form coherent masses under heavy pressure, will conduct at the ordinary temperature. Good conductors, at ordinary temperatures, have, 
as a rule, small positive temperature coëficients, but with poor conductors the coefficient is large. At a definite temperature for each substance, there is an increase in the conductivity. Foerster and Müller (Ztschr. Elektrochom., 9, 1, 1 and 105 (igo3)) contribute long articles bearing upon the theory of the electrolysis of alkali chloricles in solution. Nine summarized conclusions, based upon some twenty-one experimentally determined facts, are set forth in detail. An extended study of the electrolysis of potassium iodide solution was made by Foerster and Gyr (Ibid., p. 2I5). Rasch (Ibid., p. I62) proposes to use electrodes of oxides, such as alumina, magnesia, etc, rendering them conductors by previous heating until the resistance is reduced. for carrying on high temperature reactions, under conditions such that reductions will not take place. The ordinary furnace has a strong reducing atmosphere. Taylor and Inglis (Phil. Mag. May, . I903, p. 301) find the cause of the inertness of aluminum to attack by sulphuric acid, and the great resistance it offers to the passage of the electric current when used as an anode in sulphuric acid or a sulphate solution, is due to a film of aluninum hyclroxide, which cannot be penetrated by such ions as $\mathrm{SO}, \mathrm{OH}, \mathrm{A}$. Lorenz and Clarke (Ztschr. Elektrochem., I903, p. 269) have electrolyzed fused caustic potash and obtained 15.5 grams of metallic potassium with a current of I 3.4 amperes with electromotive force of $I 5$ volts in $7 \mathrm{I}$ minutes, corresponding to current efficiency of $; 8$ per cent. The great vapor pressure of potassium causes a metallic cloud at the cathode, which dissolves in the bath, or diffuses to the anode and is oxidized: this is the cause assigned by the authors for the difficulty of preparing potassium by electrolysis. Brochet and Ranson (Compt. rend., I36, I I34 (I903)) have electrolyzed warm, concentrated solutions of sodium sulphide; at $68^{\circ}-70^{\circ} \mathrm{C}$., with a current of 7 amperes per sq. $\mathrm{dm}$., stiphur is liberated at the anode and dissolves in the electrolyte to form polysulphides; at the cathode, canstic soda and hydrogen are produced; without a diaphragm, the sulphur finally combines with the hydrogen as sulphuretted hylrogen and regeneration of the sodium stiphide occurs. The same authors (Ibid., pp. II95 and 1258) have electrolyzed the alkali earth-metal sulphides; the results are similar to those above, hydrogen and sulphur being liberated. Keller, in a paper before the Iron and Steel Inst., reviews the use of the electric furnace in metallurgy, for ferro-chrome, ferro-silicon, steel and iron ore reduction. Fredenhagen (Ztschr. phys. Chom. 43, I-40), from a long investigation of the passivity of iron and the reactions of iron electrodes, concludes that the first is due to a film of gas on the iron surface and not to oxide or to the fact that the iron exists in two modifications. The gas may he oxygen, or nitric oxide, if the iron has been rendered passive in nitric acid. The change 
from one state to the other is periodic in some cases; the chemical action between the iron and the electrolyte is important; when the iron dissolves, or reacts with the halogen liberated by the current, the ions in solution are increased and the solubility tends to decrease. As the electrolyte around the electrode is weaker in chlorine ions, the iron becomes passive by oxygen polarization; as diffusion brings chlorine ions to the anode, hypochlorite is formed and the oxygen film is destroyed, rendering the iron active again. Just ( $Z$ tschr. Elektrochem., 1903, p. 547), in electrolyzing solutions of sodium carbonate and chlorate, with lead electrodes, found that in weak carbonate-chlorate liquor the anode potential is practically that of a lead plate in a solution containing lead ions ( 0.192 volt), but in stronger carbonate liquor this rises rapidly as the anode becomes covered with lead peroxide. In pure chlorate solution the anode potential increases with the current density. With chlorate solutions the results are more marked than with the carbonate. The gradual decrease of effective anode surface, by deposit of carbonate on the anode, in the strong carbonate solution, increases the current density till the anode potential equals that of the peroxide, which then forms. Johnson (Trans. Am. Electrochem. Soc., I903, p. 255) finds that heavy platings of nickel can be obtained if the electrolyte be freed from dissolved hydrogen by allowing the liquid to drop through a vacuum. Count von Schwerin (Ztschr. Elektrochem., I903, p. 739) proposes to remove water from wet clay, peat, alizarine paste and other similar amorphous fine slimes, by passing an electric current through the mass, whereby the water is driven to the cathode by electric endosmosis and the solid particles towards the anode; the apparatus consists of a wood vat having a brass netting for a bottom, which forms the cathode. The water being drawn to the netting quickly runs off. This new idea may find industrial use, especially in dealing with certain slimes and tailings in gold metallurgy. The migration of colloids under the influence of an electric current has some relation to electrical endosmosis. Bredig holds that the coagulation of colloids is associated with capillary electric phenomena. Buchner (Ibid., p. 728 ) reviews the use of electrochemistry in organic manufacturing chemistry; thus the formation of chloracetic acid, or the conduction of various oxidation processes at the anode (as anthranilic acid from phthalimide, or chromic acid from chromium sulphate) is now practiced quite extensively; reduction processes are more important, and by adding tin, copper or iron to the cathode compartment, reduction in acid solution is rapid; Haber found that copper powder effected the reduction of nitro-compounds to amines directly, and thus aniline may be made direct from nitrobenzene, using the hydrogen which has hitherto been wasted. Loeb and Moore (Ibid., p. 753) find 
that in reducing nitrobenzene in caustic soda solution, cathodes of platinum, mercury or nickel produce azoxybenzene: lead, tin or zinc form azobenzene, and copper yields aniline; having measured the potential of the cathodes against caustic soda alone, and against the caustic mixed with nitrobenzene, the difference is called the "depolarization value" of the nitrobenzene; by keeping this potential the same all the time, a constant yield of the same product is obtained. Harris has devised an electrolytic process (U. S. Patent 7II, 565) for making ether, in which acetylene is passed into an electrolyte of stuphuric acid diluted with 35 per cent. of water, while a current is passing; the reactions given are:

$$
\begin{aligned}
& \mathrm{C}_{2} \mathrm{H}_{2}+2 \mathrm{H}=\mathrm{C}_{2} \mathrm{H}_{4} \\
& \mathrm{C}_{2} \mathrm{H}_{4}+2 \mathrm{H}=\mathrm{C}_{2} \mathrm{H}_{6} \\
& \mathrm{C}_{2} \mathrm{H}_{4}+\mathrm{H}_{2} \mathrm{SO}_{4}=\mathrm{C}_{2} \mathrm{H}_{5} . \mathrm{HSO}_{4} \\
& 2 \mathrm{C}_{2} \mathrm{H}_{5} . \mathrm{HSO}_{4}+\mathrm{H}_{2} \mathrm{O}=\left(\mathrm{C}_{2} \mathrm{H}_{5}\right)_{2} \mathrm{O}+\mathrm{H}_{2} \mathrm{SO}_{4} \\
& \mathrm{C}_{2} \mathrm{H}_{5} \mathrm{HSO}_{4}+\mathrm{H}_{2} \mathrm{O}=\mathrm{C}_{2} \mathrm{H}_{5} \mathrm{OH}+\mathrm{H}_{2} \mathrm{SO}_{4} \\
& \mathrm{C}_{2} \mathrm{H}_{5} \mathrm{HSO}_{4}+\mathrm{C}_{2} \mathrm{H}_{5} \mathrm{OH}=\left(\mathrm{C}_{2} \mathrm{H}_{5}\right)_{2} \mathrm{O}+\mathrm{H}_{2} \mathrm{SO}_{4} .
\end{aligned}
$$

The anode is enclosed by a porous diaphragm to prevent oxidation of the ethyl-sulphuric acid.

Bleaching Agents. - Winteler has studied the formation of bleaching powder and concludes that $(a)$ dry chlorine has no action on dry calcium hydroxide, (b) chlorine water is a mixture of hypochlorous acid and hydrochloric acid, which balance each other according to the law of mass action, (c) bleaching powder is not a chemical unit, but is a variable mixture of substances, depending on the temperature, moisture and other conditions during chlorination, but basic calcium hypochlorite and basic calcium chloride are the stable constituents ( $Z$ tschr. anorg. Chem., 33, I6I (1902). Bleaching Liquors by Electrolysis.-These have had much success in Europe and are extensively used, especially in textile work, bleaching and in laundries, where dilute, rather than concentrated liquors are preferred. Three system for preparing these liquors are in use, ziz: (a) that of Siemens and Halske, using apparatus embodying ideas of Carl Kellner and Imhoff (this apparatus is also used in some paper and pulp mills); (b) the Schuckert process controlled by the SiemensSchuckert Co., of Berlin. This company also owns patents relating to the use of resin soap (sodium resinate) for decreasing the reducing action on the hypochlorite solution, of the hydrogen liberated at the cathode. The strength of the solution generally produced is about 20 grams available chlorine per liter, which is then diluted to the desired strength; $(c)$ the Haas and Oettel system, which uses no platinum, and is comparatively cheap, is employed in large cotton mills and in the laundry of the North German Lloyd S. S. Co. Each unit is intended to take about 75 amperes, and the concentration of the liquor is ultimately 
brought up to 5 grams active chlorine per liter. (W. H. Walker: Electrochem. Ind., I, 439 (1903)) (F. Haber: Electrochem. Ind., I (I903)). The advantages of the electrolytic bleach liquor for paper pulp are discussed by Neuberger (Papier Ztg., 27, 70 (I9O3)). An apparatus of high efficiency is described; liquor carrying not over 2 per cent. "active chlorine" is best prepared and then diluted with Io-20 volumes of water when used. In the apparatus, 8,000 kilos of salt are used each twenty-four hours, producing $\mathrm{I}, 600$ kilos of "active chlorine." Dorenfeldt (Ibid., 28, 215 (1903)), using Neuberger's figures, calculates that the same amount of chlorine by the Hargreaves-Bird process costs 35 marks less for materials, besides yielding sodium carbonate to the value of 175 marks additional, making a total saving of 2I 5 marks on each day's run. Walker (Eng. Min. J., Igo2, p. 679) describes the hypochlorite apparatus of the G. J. Aitkins; a semi-cylindrical wood vat with a horizontal axis, contains a revolving wooden cylinder, covered with lead, which forms the cathode. The lining of the vat is carbon bricks, which form the anode. A current of I000 to I 500 amperes at 3 to 4 volts is used in a Io per cent. solution of salt, and converts 500 or more gallons per hour. Carey and Muspratt (J. Soc. Chem. Ind., rgo3, p. 674) have studied the preparation of bleaching powder solutions, having in view (I) the variations in the powder itself, (2) the effect of temperature and prolonged agitation of the solution on the rate of settling; long agitation is considered only a waste of time, the full strength being reached in twenty minutes, with good agitation at the start. The last few inches of the settling of the sludge are very slow, hence the draw-off pipe should be high enough to allow $5 \mathrm{cu}$. ft. of sludge per cwt. of bleaching powder. Bleach is made as a by-product from the Hoepfner zinc process in the Brunner-Mond works at Winnington, Eng.; about 6 tons of zinc and $\mathrm{I} 8$ tons of bleach is said to be the daily output (Eng. Min. J., I903, p. 750). Guenther (Eng. Min. J., I903. p. 750) describes the Brunner-Mond process for zinc with bleach as a by-product; zinc oxide, calcium chloride and carbon dioxide are heated under pressure to form calcium carbonate and zinc chloride, which is then electrolyzed in Hoepfiner cells to obtain the zinc.

Ozone.- The apparatus of Siemens and Halske for water purification is described at length in $Z t s c h r$. Elektrochem., I902, Nov. 29, and in the same paper Professor van't Hoff describes some tests with the Vosmaer-Lebret apparatus, which were successful. The ozone is used for sterilizing water (see this Journal, 24, R 327 and 25, R 234). Kausch (Electrochem. Ztschr., 1903, July, August) discusses the production of ozone by the apparatus of Tindal, Otto, Siemens-Halske, Yarnold and Verley. Proskauer (Biochem. Centrbl, I903, p. 209) gives data concerning 
the various installations of apparatus for water sterilization by the use of ozone. A plant at Lille was said to destroy the spores of $B$. subtilis., and a Siemens-Halske plant near Berlin, destroyed cholera vibrios and typhus germs completely in Spree water. This apparatus gave some unsatisfactory results, owing to too large packing in the sterilizing tower. Linde (Ztschr. Ver. Deutsch. Ing, 46, 1.73) (lescribes his apparatus for producing oxygen by the fractional evaporation of liquid air.

\section{ACIDS.}

Sulphuric Acid.-The contact action of ferric oxide for the production of sulphur trioxide has been studied by Lunge and Pollitt, in a series of laboratory experiments (Ztschr. angew. Chom.. I5, I IO5 (IgO2)). They find that the percentage conversion is not affected when the concentration of the sulphur dioxide is raised up to $\mathrm{I} 2$ per cent., but diminishes above this; the contact substance is injured if there be moisture in the gases; access of air to the contact mass also reduces its efficiency; attempts to increase the porosity of the mass gave no better effect, but the physical state of the surface is cloubtless important; a mixture of ferric and cupric oxides (from copper-bearing pyrites) gave better efficiency; at temperatures of $700^{\circ} \mathrm{C}$. and over. drsenic combines with the ferric oxide, and the efficiency is increased; the reaction runs best between $600^{\circ}$ and $620^{\circ} \mathrm{C}$. Under $600^{\circ}$ combination between the sulphur dioxide and oxygen does not occur, while above $620^{\circ}$ and up to $750^{\circ} \mathrm{C}$. there is a slight decrease of efficiency; above the latter temperature the drop is rapid. The contact process is gradually extending both here and abroad. The Schroeder-Grillo patents, controlled by the New Jersey Zinc Co., are in use by several firms in California and Wisconsin, near Wilmington, Del., and at Philadelphia. A plant under the patents of the Verein Chemische Fabriken, Mannheim, in which burned pyrites cinder is used as contact mass, has begtm operations in Buffalo. Papers on the contact process were read in the New York section of the Society of Chemical Industry by Doctors T. Meyer, Reese, and Mr. George C. Stone. Meyer's tangential chambers appear to be gaining favor with manufacturers and many are now in operation or building ( $Z$ tschr. angew. Chem., I5, 278 (1902)). Lunge states that the yield by this system is less, reckoned on a unit of chamber space, than by the so-called "intense" system of working, employed in France. Introduction of the water necessary to the process in the lead chambers, in the form of spray, has long been a desideratum, but difficulties caused by clogging of the apparatus by dirt, and the lack of a suitable resistant material from which to make the apparatus, have prevented general use of any of the methods proposed. Kestner ( $J$. Soc. Chem. Ind., 22, 333 (1903)) has recently de- 
vised improved apparatus for this purpose, from which good results are expected. Benker and Hartmann report upon forced draught and atomized water in the chamber process; they advocate $a$ fan at the end of the system and enumerate its advantages thus: The process is more regular and independent of whims of the workmen; an increased yield with the same consumption of niter; a saving of fuel; lead corrosion reduced; interest and depreciation charges less (Ztschr. angew. Chem., I903, pp. 86I-869). In the chamber process, the use of fans is increasing; a special kind of cast iron fan, behind the burners and in front of the Glover tower, is being experimented with in a few plants. It has generally been held that the fan should be between the Glover tower and the first lead chamber, as this causes a suction in the burners and Glover tower, with a pressure in the rest of the system. Kestner (J. Soc. Chem. Ind., I903, p. 334) disputes this view, and favors placing the fan at the end of the system, behind the Gay-Lussac tower. His fan is made of regulus metal, set in a casing of the same metal or of volvic stone. Petschow ( $Z$ tschr. angew. Chem., I903, pp. 12-14) reviews the employment of fans in making sulphuric acid; an earthenware fan between the Glover and the first lead chamber in a works at Danzic, proved a failure; a lead fan in another case was also not satisfactory. He concludes that fans between the Glover and the first lead chamber, or between the burners and the Glover, are inadvisable; yet he considers it not expedient to suck the gas through the system, but to drive it under slight pressure. The Kessler method of concentration is apparently extending, both abroad and in this country, and seems generally satisfactory. Zanner (U. S. Patent 693,695) concentrates acid in cast iron pans, set in the gas flue from the burners; the pans have covers to exclude flue dust, and openings allow the vapors to escape; acid of $60^{\circ}$ Bé. from the Glover tower is concentrated to $66^{\circ}$ Bé. It is proposed to apply vacuum to the pans to increase the capacity. Conroy (J. Soc. Chem. Ind., Igo3, p. 465) has examined the action of sulphuric acid on platinum; pure acid has a marked solvent action which is most rapid at the start, and in some cases amounts to 3000 grains per ton of acid concentrated; the rate of solution is nearly uniform for all acid above 92 per cent. $\mathrm{H}_{2} \mathrm{SO}_{4}$, and is largely dependent upon the temperature, being quite rapid at $250^{\circ} \mathrm{C}$. and very slight under $200^{\circ} \mathrm{C}$.; it is not affected by such impurities as ammonium sulphate, ferrous and ferric sulphates, sodium chloride and nitrates, but is accellerated by sodium arsenate and platinic chloride, while arsenic trioxide, carbon, sulphur and sulphurous anhydride retard the solvent action. Reducing matter in the acid is generally beneficial in preventing solution. Nitrogen oxides probably do act injuriously, indirectly, by oxidizing and destroying the reducing substances 
present. Hart and Bailey (Ibid., p. 437) have described an addition to the chamber plant for sulphuric acid. A couple of towers, Io feet high, by 4 by 5 feet section, joined by a lead trunk 2 feet square in section and 40 feet long, are put between the first and second chambers. Through each of these towers, pass 28 vertical tubes, 4 inches in diameter, open to the air at the top and bottom, while through the trunk pass 98 such open tubes. The gases from the first chamber pass through these towers and trunk, and are cooled materially, and are, at the same time, thoroughly mixed. The sulphuric acid mist present is condensed, and the nitrous gases recovered for further use. Porter (Ibid., p. 476) discusses draught in vitriol chambers. By constructing a model chamber of glass, into which vapors from smouldering brown paper, or hydrochloric acid and ammonia, could be introduced at various heights by means of a sliding door, the directions taken by the vapors could be readily seen, and it was at once shown that the position of the inlet has a marked effect on the movements within the chamber. It is concluded that the gases should enter at the bottom of the chamber, and the steam be so admitted at either end as to mix with the center core of incoming and out-going gases. Bodlaender and Koeppen (Ztschr. Elektrochem., 9, 559-568, 787794 (1903) have made a long study of the theory of the contact process. The articles are not adapted to very brief abstraction, but among the conclusions drawn, they find that dilution of the gases with an excess of air retards the reaction in the beginning, but increases it later and that the final 95 per cent. conversion is reached sooner, and space and contact substances are economized when the air exceeds the theoretical quantity needed; the reaction corresponds more nearly to a tri-molecular than to a bimolecular one; the concentration of the sulphuric anhydride formed affects the rate of the reaction, this being slower as the anhydride increased; the reaction speed is influenced by the contact substance and by the temperature, and with substances other than platinum, the temperature must be so high that the clissociation pressure of sulphur trioxide becomes important; pressure within the apparatus assists the reaction, and the authors anticipate this as an industrial possibility. Details of an apparatus patented by the Color Works at Hoechst a.M. for producing sulphuric anhydride with pyrites cinder as contact borly, have been published in Ztschr. angew. Chem., 16, 327; in the same volume $(16,352)$ the use of iron, chromium or copper oxides, instead of asbestos, as foundation for a platinum contact mass, is described.

Sulphur Recovery.-Carpenter and Linder ( $J$. Soc. Chem. Ind., r903, p. 457) have studied the reactions in the Clatis sulphur recovery. The results of careful heat measurements in the kiln are tabulated, as are also the results obtained with manganese oxides as contact material instead of ferric oxide. 
Nitric Acid.-J, de Kowalski obtained 43.5 grams nitric acid per kilowatt-hour with a current of 0.2 ampere in the arc. Decrease of the current intensity causes an increase of the relative quantity of nitrous vapor, and the length of the arc also affects the yield somewhat. The highest percentage yield was obtained with a current of 0.05 ampere at 50,000 volts and a frequency of 6,000 to 10,000 cycles per second, when 52 to 55 grams nitric acid per kilowatt-hour resulted. By introducing 50 per cent. oxygen, the yield of acid was nearly doubled (Electrochem. Ind., 1, 462 (I903)). Bradley and Lovejoy have patented an apparatus for the production of nitric acid from the nitrogen and oxygen of the air, by means of electrical spark discharges under high tension. Although yet in the experimental stage, some very encouraging results are reported. Muthmann and Hofer (Ber.d. chem. Ges., 36, 438-453 (1903)) have experimented on the production of nitric oxide by burning nitrogen in the electric flame. With air, the quantity of nitric oxide formed in a unit of time, was proportional to the rate of flow of air through the flame; the percentage of nitric oxide in the products is fairly constant for any given temperature, and is larger the higher the temperature. The reaction appears to be merely a thermal effect. The production of a gram-molecule (30 grams of nitric oxide) requires about 0.5 horse-power-hour, or $4 \mathrm{kw}$.-hour. This makes the cost of I kilo of nitric acid, under most favorable conditions, about 16 pfennige against a market price of 70 piennige for $\mathrm{I}$ kilo of 50 per cent. acid. There are, however, many difficulties in working, and the conversion is incomplete. Von Lepel (Ber. d. chem. Ges., I903, p. I25I) brings air and water in the vapor or atomized state into the sphere of electric reaction; he finds that the yield of acid is affected by the material of the electrodes, and also by the conditions of the electric discharges. Volney (J. Soc. Chem. Ind., I903, p. 780) reviews the commercial manufacture of nitric acid by various methods; the processes using atmospheric nitrogen all yield dilute acid, and must meet the cost of concentration to compete with acid from natural nitrates. Veley and Manley (Ibid., I903, p. 1227) have determined the densities of concentrated nitric acid at various temperatures; the percentages range from 62.3 to 100 per cent. and the temperatures of observation were $4^{\circ}, 14.2^{\circ}\left(15^{\circ}\right)$, and $24.2^{\circ}\left(25^{\circ}\right) \mathrm{C}$; ; a comparison with the similar table of Lunge and Rey shows differences generally less than I part in 300 , except between 77 and 86 per cent. acid, where the difference was about I part in 220.

Alkali.-Bryant ( J. Soc. Chem.Ind., 1903, p. 785) reports upon the natural soda deposits of Egypt. A range of eleven lakes, composing a total of nearly $12,000,000$ sq. m., contains about 100,000 tons of alkali in solution. The lakes have no outlet and 
are fed by alkaline springs, and the author calculates that about I 5,000 tons of sodium carbonate are deposited per annum by evaporation of the water.

Pigments.- Herting (Chem. Ztg., 27, 923 (I903)) lias studied the effect of foreign metals upon lead when used for pigments. Bismuth renders lead unsuitable for red lead, but not for white lead: copper causes the white lead to be greenish, and silver also gives it a greenish tint. Kuegelgen ( $Z$ tschr. Elcktrochon.. 9, 239 (I903) has investigated the production of copper and nickel from their alloys, and the formation of certair pigments at the cathode as by-products. Anoles of lead, copper and zinc were used with various electrolytes, such as sodiun chloride, sulphate, chromate, chlorate, bichromate and hydroxide: one salt being employerl to dissolve the anode and the other to act as a precipitant: the clissolving and precipitating salts are regenerated so long as the anode compartment contains the precipitating agent; but this steadily accumulates in the cathode compartment, reducing the amount at the anode. The pigments wore generally not satisfactory, but by causincr the precipitation in special vessels, away from the anorle compartment, better results were obtained.

Cement.-Bleininger (Trans. Am. Ceram. Soc, 5, 74 (1903)) has studied the reactions of cement making. He finds that when a mixture of clay and amorphous calcium carbonate is heated, decomposition of the clay by the lime sets in soon after the carbon dioxide has begm to be liberated. At $850^{\circ} \mathrm{C}$. the clay is entirely decomposed. At $950^{\circ} \mathrm{C}$. combination of the free silica in the mixture (if sufficiently fine) with the lime begins; but coarse particles, which will not pass the $120-$ mesh sicve, are not attacked until the temperature is above $1350^{\circ} \mathrm{C}$. Felspathic materials are ahout as readily decomposed by the lime as is clay. Newberry and Smith (Ceinent and Engineering News. !(p2). in continuation of some previous work (J. Soc. Chem. Ind., I897, pp. 887-893), find that on calcining very finely powdered calcium carbonate and silica, a tricalcium silicate, $3 \mathrm{CaO}$. $\mathrm{SiO}_{\ldots}$, is produced, having a specific gravity of 3.055 , and free from uncombined silica or lime. It sets slowly with water and hardens well. By heating the ingredients for two hours at a red heat, basic compounds are produced, and free uncombined silica is left, unless there be more than $2 \frac{1}{2}$ molecules of lime. Put at a white heat the various mono-, di- and trisilicates are completely combined. The porosity and mechanical conditions of the mass have much to do with the amount of water necessary to combine with any specified cement. Seger and Cramer have shown that blast-furnace slag and Portland cement have noticeable differences in respect to their water-absorbing capacity and their solubility. The amount 
of water of hydration for Portland cements averaged II.46 per cent., and for slag only 0.78 per cent. A considerable difference in solubility in the two substances was also found (Chem. Ztg., I903, p. 879). Cloez (Bull. Soc. Chim., 29, I69 (I903)) has studied the burning and setting of plaster of Paris; pure gypsum, heated to $145^{\circ} \mathrm{C}$. for four hours was entirely dehydrated, but on exposure to the air it reabsorbs about 8 per cent. moisture. When mixed with water, a rapid rise of temperature at first takes place, followed by a fall of about $6^{\circ}$, and later by another rise. The first rise is due to hydration; the drop of temperature indicates the solution of the hydrated sulphate and the final rise is due to the setting of the plaster. Richards (Thonind. Ztg., 27, 942 (1903)) considers Portland cement as a solid solution of tricalcium silicate and dicalcium aluminate, containing about 85 per cent. of silicate and I 5 per cent. of aluminate. In commercial cement, an iron-lime compound replaces more or less of the aluminate; magnesia, sulphuric acid and the alkalies are nonessential, and should not be present in sufficient amount to interfere with the formation of the solid solution. For good cement, the calcium silicate must be a tribasic form. Rohland (Ztschr. angeze. Chem., I6, 1049 (1903)) has examined the effects of various salt solutions upon the hydration of Portland cement. These salts act as catalytic agents, but the effect produced depends upon the concentration of the catalyzer and on the velocity of hydration of the cement. Materials rich in alumina yield quick-setting cements, while the presence of soluble silicates tends to form slow-setting cements.

Glass, Pottery, Etc.-Mylius (Fifth International Congress of Applied Chemistry, Berlin, 1903, p. 592) reports upon glass for chemical purposes; the resistance to chemical attack varies with the reagents used. Saline solutions which are hydrolyzed, attack glass, owing to the free alkali they contain. Dilute acids have no action, but boiling concentrated sulphuric acid and metaphosphoric acid at high temperatures cause decomposition. Caustic soda has destructive action on all kinds of glass and even on fused quartz. Common green bottle glass appears to be the most resistant to chemical action. Vogt (Chem. Ztg., I903, p. 606) has investigated the influence of kiln temperature upon porcelain, and finds that the coefficient of expansion is modified by changes in temperature of not more than $100^{\circ} \mathrm{C}$. Mülhaüser (Ztschr. angew. Chem., I6, 32I) has examined firebricks from St. Louis (Mo.) clay, made for use in zinc furnaces. The bricks were burned at a temperature slightly under that of the melting of Seger cone No. 8. The porosity was 25.5 per cent. (water absorbed). The temperature in the zinc furnace ranged from 1200 to $1300^{\circ} \mathrm{C}$. about fourteen hours out of the twenty-four. Anal- 
yses of the bricks before and after seventy-five months' use showed that but little chemical change, except in the surface, had taken place; the surface was glazed about io $\mathrm{mm}$. deep; the glazed portion showed a decrease in the alumina, iron and silica, with noticeable increase in the alkali content. The bricks became thinner, owing to fusing away of the surface and the whole brick had shrunk from $5 \mathrm{I}$ cc. to $45.3 \mathrm{cc}$. per Ioo grams. Binns (Trans. Am. Ceram. Soc., 1903, p. 50) publishes the formulae for certain "matt" glazes on pottery; silica, between 1.2 and 2.5, gave matt surfaces, the best being 1.95 , and the matt texture is thought to be due to particles of uncombined alumina, suspended in the glaze: barium permits reducing the amount of alumina used; some lead is necessary, while zinc, lime and potash in the glaze are all useful. Purdy (Ibid., p. I 36 ) has made extensive experiments on "White Bristol" glazes, and various formulae are given; the influence of alumina, clay, felspar and silica was studied. Richs (La Ceramique, 33, I I I (I903)) has tabulated the charges of metal for mirror glass in France, England, Germany, Belgium, Russia and the Lnited States, and from these proportions the perecentage formulae for charges have been deriver.

The manufacture of chemical vessels of fused quartz has reached a successful issue in Germany. Dishes and crucibles are now articles of commerce. Owing to the very low coefficient of expansion of quartz it is little affected by extremes of heat and cold, and its inertness makes it useful for acid vessels, pump valves, etc. It withstands water, acids and neutral salts, but not alkaline liquids and dry oxicles at high temperatures. Being transparent to ultra-violet rays of the spectrum, fused quartz is suggested for vacuum tubes.

Explosives.-Standard regulations for making lead cylinders, and their use for determining the strength of explosives, were proposed at the International Congress of Applied Chemistry at Berlin. The cartridge is put into the central hole in the cylinder and pressed down, the hole being filled with dry sand which has passed a mesh I 44 to sq. $\mathrm{cm}$., with wires $0.35 \mathrm{~mm}$. diameter. The volume of water in cubic centimeters, needed to fill the cavity caused by exploding the cartridge, less the volume of the original hole, is a direct measure of the strength of the explosive (Chem. Z tg., 1903 , p. 898). Petavel (Engineering, 76, 452 (1903)), in a study of the explosion of cordite where pressures of 2,000 atmospheres were reached, found that the explosion is more rapid with the more finely divided material: that it was quicker the higher the pressure; that doubling the charge increased the pressure more than twice; and that in a cylindrical container the charge cooled four times as fact as in a spherical bomb. Sy (J. Franklin 
Inst., 155, I6I (1903)) reviews the various stability tests proposed for nitrocellulose and nitrocellulose powders. At the U. $\mathrm{S}$. Arsenal at Frankford, Pa., the Abel test, the explosion test, the Vieille test, and the German or $135^{\circ} \mathrm{C}$. test, are used and are considered sufficient. The author has also devised a new stability test for nitrocellulose powders (This Journal, 25, 549 (1903)). Vignon (Compt. rend., 136,898 ) finds the composition of oxycellulose to be $\left(\mathrm{C}_{6} \mathrm{H}_{10} \mathrm{O}_{5}\right)_{3}+\mathrm{C}_{6} \mathrm{H}_{10} \mathrm{O}_{6}=\mathrm{C}_{24} \mathrm{H}_{40} \mathrm{O}_{21}$. The analysis of nitrocellulose of highest nitration corresponds to $3\left[\mathrm{C}_{6} \mathrm{H}_{7}\left(\mathrm{NO}_{2}\right)_{3} \mathrm{O}_{5}\right]+\mathrm{C}_{6} \mathrm{H}_{7}\left(\mathrm{NO}_{2}\right)_{3} \mathrm{O}_{6}=\mathrm{C}_{24} \mathrm{H}_{28}\left(\mathrm{NO}_{2}\right)_{12} \mathrm{O}_{21}$. The author considers nitrocellulose to be a derivative of oxycellulose. Cap't Lloyd, inspector of explosives, in reporting upon an explosion of nitroglycerine in the Nobel's Explosive Co.'s works, assigns the most plausible cause to be friction of the air pipes on the bottom of the tank in the wash house. Rubber rings have now been placed on the pipes to prevent their coming in contact with the tank. Vieille (Mem. des Poudres et Saltpêtres, I I, I 57) has examined the erosion of rifled guns by various explosives. The erosion is supposed to be due to leakage of the explosion gases, past the projectile, before this has attained its full velocity. The apparatus used contained a plug, with a very fine opening through which the gases escaped; from the loss of weight in this plug the volume of erosion was determined. It was found that the erosion was greater as the diameter of this gas canal was less, and as the length of the tube was increased; with equal gas pressure, the smallest explosive charges produced greatest erosion; the erosion decreased with each successive use of the same plug; the addition of nitroguanidine decreases erosion noticeably. Dupré (Rep. H. M. Inspectors of Explosizes for I902) found that nitroglycerine could not be exploded on sheet lead, I inch thick, supported on a stone bed, by either direct or glancing blows from iron or steel. Thin layers on any surface were more difficult to explode by percussion than moderately thick layers. The presence of small amounts of potassium perchlorate in the nitrate used for gunpowder was found to have no injurious effect on the powder. Hake (J. Soc. Chem. Ind., Ig03, p. I 224) proposes the use of the X-ray for the examination of "Safety fuses." The powder train in a fuse is sharply defined upon a luminous screen by a Crookes' tube, and any break in continuity is at once detected.

Cyanides.-Adair (Eng. Min. J., April II, I903) describes a method for the determination of true cyanide in commercial potassium cyanide. Rutten's modification of Knublauch's wet process for cyanogen recovery from illuminating gas, is in successful use at the Hague gas works. Basic ferrous carbonate, made by mixing hot solutions of copperas and soda, and washing the 
precipitate, is suspended in water and agitated in contact with the gas; a precipitate of ferrous sulphide, ammonium ferrocyanide and Prussian blue is filter-pressed and distilled with caustic potash; ammonia is evolved and potassium ferrocyanide crystallized from the lye ( $J$. Gas Lighting, I903, p. 879). Later investigation by Jorrissen and Rutten ( $J . f$. Gasbeleucht., I903, p. $7 \mathrm{r} 6$ ), on the nature of the reactions in the scrubber, led to the conclusion that the ferrocyanide precipitates have the composition $\left(\mathrm{NH}_{4}\right)_{2} \mathrm{Fe} . \mathrm{Fe}(\mathrm{CN})_{0}$ and $\mathrm{K}_{2} \mathrm{FeFe}(\mathrm{CN})$;. Täuber (Chem. Ind., $26,26)$ has examined the action of iron in the synthesis of cyanides, by heating to redness in a gun barrel, calcined soda, nitrogen and reduced iron powder. An average of ro per cent. of the soda was converted to cyanide, but higher yields were obtained in some cases. Bueb (J.f. Gasbeleucht., 46, 8I ) states that the yield of cyanogen is dependent on the coal and on the temperature of distillation; the amount of Prussian blue in the cyanide mud from various coals is given in grams per cubic meter of gas. English coal, 4.45; Upper Silesian, 2.87; Westphalian, 3.55. The small cyanogen content of gas from coke ovens makes the recovery from them unprofitable. Erlwein (Ref. Sec. II, V, Intern. Kongress $f$. angezu. Chem., Berlin, Igo3) reports on the making of potassium cyanide by the Cyanidgesellschaft m. b. H., Berlin. As raw material, the cyanides of alkali earths are userl, in making which the nitrogen is obtained from the air. Attempts to thus fix the nitrogren have long been tried, without success. The process had its origin in the patents of Caro and Frank (Goman Patents $88,363,92,587,95,660$, I08,97 I, II 6,087 , I 6 , 088) in which barium cyanicle is procluced from carbide and then converted to cyanide $(\mathrm{CN})$; hit it has been found that calcium carbide is a more suitable raw material, since it takes up atmospheric nitrogen to form a cyanide;

$$
\mathrm{CaC}_{2}+\mathrm{N}_{2}=\mathrm{CaCN}_{2}+\mathrm{C} \text {, }
$$

and carbon remains in the mass. The carbide may be heated per cent. of the theoretical quantity of nitrogen to form a black in direct-fired muffles or in electric furnaces, and takes on 85-95 mass of calcium cyanamide, having 20 to 23.5 per cent. fixed nitrogen, of which $90-95$ per cent. is converted to cyanide in the next fusion. The lixiviation and separation of the commercial sodium cyanide is not difficult. Later improvements in the process have shown that the calcium cyanamide can be produced directly in the electric furnace from a coke-lime charge:

$$
\mathrm{CaO}+2 \mathrm{C}+2 \mathrm{~N}=\mathrm{CaCN}_{2}+\mathrm{CO} \text {. }
$$

It also appears that the cyanide, by a simple extraction process, yields a crystalline di-cyanamide, having the appearance of sal ammoniac. This di-cyanamide is capable, by simple fusion with soda, of conversion into a white IoO per cent. commercial sodium 
cyanide, while some ammonia and a mixture of volatile cyanamides escape from the fusion. The reactions of the di-cyanamids process are:

$$
\begin{gathered}
2 \mathrm{CaCN}_{2}+{ }_{4} \mathrm{H}_{2} \mathrm{O}=2 \mathrm{Ca}(\mathrm{OH})_{2}+\left(\mathrm{CN} \cdot \mathrm{NH}_{2}\right)_{2} \\
\left(\mathrm{CN} . \mathrm{NH}_{2}\right)_{2}+\mathrm{Na}_{2} \mathrm{CO}_{3}+2 \mathrm{C} \underset{2 \mathrm{NaCN}}{=}+\mathrm{NH}_{3}+\mathrm{H}+3 \mathrm{CO}+\mathrm{N} .
\end{gathered}
$$

The Cyanidgesellschaft has also discovered that by fusing the calcium cyanamide with common salt, a mass with 30 per cent. alkali cyanide content is obtained at a very low cost. This is good enough and much cheaper for gold extraction than the pure potassium cyanide. It is on the market as potassium cyanide surrogate.

Gas.-Frank reports on some experiments with the PippigTrachmann process for removing sulphur bodies from coal gas. Carbon disulphide is removed by uniting with aniline in the presence of a little sulphur, forming sulpho-carbanilide;

$$
\mathrm{CS}_{2}+2 \mathrm{C}_{6} \mathrm{H}_{5} \cdot \mathrm{NH}_{2}=\mathrm{CS}\left(\mathrm{NH} . \mathrm{C}_{6} \mathrm{H}_{5}\right)_{2}+\mathrm{H}_{2} \mathrm{~S}
$$

The scrubbing liquor consists of anthracene oil, containing certain amounts of heavy tar bases; with 5 per cent. aniline, 5 per cent. benzene to prevent the oil absorbing that present in the gas, and 0.2 per cent. sulphur as a contact body. This liquor, used in the scrubbers, removes a large amount of naphthalene and about $\% / 7$ of the sulphur in the gas, including all of the carbon disulphide and thiophene ( $J . f$. Gasbeleucht., 46, 488 (I903)). White and Mueller have studied the cause of loss of illuminating power in mantles, and conclude that the loss of cerium oxide by volatilization is the important factor. The loss of cerium is relatively much greater than that of thorium ( $J$. Gas Lighting, 83, 504-508 (Ig03)). Lange (Ztschr. angew. Chem., Igo2, p. I307) has investigated the causes of explosions of cylinders of compressed gases. This is frequently due to "overfilling." The author thinks that safety valves should always be put on such cylinders; valves of the Halt, Henderson Kunheim \& Co., and Brin's Oxygen Co., are illustrated and described. Caro (Ztschr. Calcium Carbid Fabrikat., I902, pp. 27I, 279, 287, 295) has examined the properties of acetylene, caburetted acetylene and air gas. Atmospheric burners for acetylene have not generally been successful, but by certain devices trustworthy burners are produced. Mantle burners for acetylene were examined and their illuminating efficiency ranged from 2.4 to 5.5 Hefner units per liter-hour. Carburetting decreases the explosiveness of acetylene materially, and the author suggests the addition of petroleum spirit or acetone vapor to the gas. With air gas, cooling is serious, since it lowers the heat value and increases the liability to explosion, even though no more air be added to the gas. Thorpe (Proc. Chem. Soc., I9, I4) finds that a Bunsen lamp, fed with coal gas, at the rate of 6 
cu. ft. per hour, at 0.95 inch pressure, evolves about $0.022 \mathrm{cu}$. ft. of carbon monoxide, when burning under a sand-bath in such a manner that the inner cone of the flame strikes the iron dish. Ballantyne ( $J$. Gas Lighting, 82, 755) describes his new process of continuous vacuum distillation of gas-liquor. The still is worked under I3 to $I_{5}$ inches of mercury vacumm, and the vacuum in the saturator is about 22 inches; the crystallizing point in the saturator liquor is about $57^{\circ} \mathrm{Tw}$. The solubility of acetylene in acetone is to be utilized in England for storing and shipping this gas; the solution at $15^{\circ} \mathrm{C}$. contains 24 volumes of gas, which may be increased by raising the pressure. Würtenberger (Stahl u. Eisen, 23, 448), in studying the loss of carbon monoxide in a Siemens regenerator, found the decomposition to occur only when the gas pressure is cut off and a partial vacuum caused by the chimney draught. The decomposition of carbon in the regenerators is according to the reaction

$$
2 \mathrm{CO}=\mathrm{CO}_{2}+\mathrm{C} \text {. }
$$

Incandescent Illumination.-Killing $(J . f$. Gasbeleucht., 46, 445 (1903)) has made a calorimeter strudy of the action of rate earths in the incandescent mantle. A mantle of pure thoria gave the calorific value of the gas as $4 \mathrm{I} 33 \mathrm{Cal}$, a thoria-ceria mantle showed it to be 4 OI $5 \mathrm{Cal}$.; thus the ceria has increased the radiation from the mantle by 13.9 per cent.; solutions of iridium or rhodium caused a loss of I 3 per cent., but thoria, yttria or erbia solutions had no effect on the radiation. The rise in temperature, as shown by a thermometer, was increased I4 per cent. by ceria and by salts of platinum, but not by thoria, yttria or erbia. The author considers the action of ceria to be chemical and catalytic, producing an intense local combustion of the gas and radiating a larger proportion of energy as light.

Destructive Distillation.-Boernstein (Ber. d. chem. Ges., 35, 4324-4325 (1902)), by distilling certain Silesian and Westphalian coals at very low heats, obtained tar liquors containing catechol. The author regards the presence of this substance as a characteristic proof of vegetable origin, even in fossil remains. Freso (Ztschr. angew. Chem., I903, pp. II-I2) has discovered $\alpha$-picoline in lignite tar, although in very small quantity, about 25 grams being separated from I4 kg. of the tar bases. Smith ( $f$. Soc. Chem. Ind., 1903, p. 201) reports the finding of selenium in coke to the amount of 0.015 per cent. in some samples. Kraemer and Sarnow (Chem. Ind., 26, 55 (Ig03)) have devised an apparatus to determine the melting-point of coal tar pitch, which has prover! successful in numerous German worls.

Photography.-Ostwald and Gros (Chem. Ztg., 27, I I 7 (1903)) cause metallic platinum or silver to act as catalyser in the decomposition of hydrogen peroxide in producing catatype pictures. 
The negative is flooded with an alcoholic or ether solution of the peroxide, and wherever the metallic deposit is, the peroxide is converted into water, while in the clear parts the peroxide is not changed. By contact with gelatin paper in a printing frame the unchanged peroxide is taken up by the gelatin, and if then treated with alkaline lead or manganese solutions, the image is produced in the brown peroxides of these metals; or if alkaline silver solution be used, the picture is in black metallic silver. The catatype process may be used in photo-mechanical work, as the gelatin film which holds the hydrogen peroxide, will absorb fatty inks, in the same way as bichromated gelatin. Miethe (Chem. Ztg., Ig03, p. 195) prepares color sensitive photographic plates by dipping ordinary plates into a $\mathrm{I}: 50,000$ solution of ethyl red. Three color screens are used with these plates, which divide the spectrum near the lines $D$ and $F$. To develop the plates, the lamp light is passed through two gelatin screens, one dyed with brilliant yellow, I : 30 , and the other with methyl violet, I: Ioo. Ebert (Chem. Ztg., 27, Rep. I52), by treating negatives with hydrogen peroxide in ether solution, obtains a white deposit which may be a means of intensifying; it is soluble in water and can thus be reduced by washing. Bromide prints treated thus and exposed to air for several days, gradually take on a brown tone, and when again developed, permanent sepia or red tones are obtained. Metol-hydroquinone or rodinal are recommended for this development.

Paper and Pulp.-Buehler (Chem. Ind., 26. i 38 ) reports that at temperatures above $150^{\circ} \mathrm{C}$. phenols dissolve the incrusting resins and lignin of wood, and liberate the cellulose. Wood tar oil of high phenol and cresol content is very good. Copper digesters must be used, and the cellulose finally washed free from phenols by benzene, leaving a pale brown pulp. Wuerster (Papier-Ztg., 28, I896 (I903)) advocates the use of sodium bisulphate for the precipitation of rosin in paper sizing; I part of bisulphate does the work of three parts of aluminum sulphate; the bisulphate may be added in the stuff chest to avoid corroding the knives of the beating machine. Sizing is held to be due to the precipitation of free rosin.

Coal Tar Colors.-Junghahn (Chem. Ind., 26, 57 (1903)) has improved the "baking process" for making sulphonic acids of aromatic bases, whereby pure products are obtained, with considerable saving of time. The acid sulphate of the base is heated to $160^{\circ}-220^{\circ} \mathrm{C}$, , and a current of air or carbon dioxide blown through the fused mass. Sulphanilic acid of light color and good purity is made thus from acid aniline sulphate. Ahrens and Bluemel (Ber.d. chem. Ges., 36, 2713 (I903)) have found in the residue from the manufacture of aniline, chlorbenzene and 
other highly chlorinated benzene derivatives, and a mixture of methyl- $\alpha$-methylbutylketone and ethylpropylketone. Meyer and Maier (Ibid., 36, 2970 (I903)), in a study of the alkylated azo dyes, conclude that amino or hydroxyl groups are not essential to the dyeing property. In the case of Diamine Gold Yellow, and Chrysophenine, the affinity for cotton is ascribed to the sulphonic groups in their constitution, and their fastness to alkali is due to the ethyl groups which they contain. Vidal (Monit. Scient., I6, 870 (1902)) has developed a method to make substituted diphenylamines with a nearly theoretical yield. By heating a mixture, $e . g ., p$-phenylene diamine and $p$-aminophenol hydrochloride to $200^{\circ} \mathrm{C}$. for four hours in an antoclave, he forms aminohydroxydiphenylamine, and others in a similar way. The author also discusses his process for sulphur dyestuffs (Ibid., I7, II 3 (Ig03)). Barillet (Rev. Gon. des Nat. Col, Ig03, pp. 6-Io) has studied the effect of substituting groups joined to the imino radical of aromatic compounds used for the production of sulphur dyestuffs upon the color of the resulting dye. Formyl and benzoyl derivatives of $p$-nitraniline yield green and yellow-green; these derivatives of $m$-nitraniline yield blacks ; acetyl- $m$-nitraniline gives brown, while acetyl-o-nitraniline gives yellowish brown. I,4-diacetamino, I,4-diacetamino-2-nitro-, and 1,2,4-triacetaminobenzene, when fused with sodium polysulphide, all gave similar browns. The acetyl derivatives of safranine vield purple, but safranine itself yields black. Cain and Nicoll (Proc. Chem. Soc., I8, pp. 244-245), in further continuance of their study (Trans. Chem. Soc., 81, 14I2 (IgO2)) of the decomposition of diazo compounds, find that with soluble diazo compounds from $\alpha$ - and $\beta$-naphthylamine, the naphthylamine mono- and disulphonic acids and the amino-naphthol-disulphonic acids, the reaction is unimolecular, but in some cases is hindered by the formation of azo dyes, this being shown by a decrease in the value of $\mathrm{C}$ as calculated by the equation:

$$
\frac{\mathrm{I}}{t} \log \mathrm{A}-x=\mathrm{C}
$$

when $\mathrm{A}=$ total nitrogen, and $x=$ volume of nitrogen evolved in the time, $t$. With the insoluble diazo salts from the naphthylamine-sulphonic acid, and the amino-naphtholsulphonic acid, the decomposition is expressed by

$$
\frac{x}{t}=\mathrm{K}
$$

where $x=$ the volume of nitrogen evolved in the time, $t$. When azo dyes are formed, the value of $\mathrm{C}$ or $\mathrm{K}$ is constant for some time, but then decreases, and it is presumed that this is due to the necessity of hydrolytic dissociation of the diazo salt before 
combination takes place between it and the naphthol-sulphonic acid. The authors (J. Soc. Dyers and Colourists, I9, p. I02) have also examined the stability of diazo solutions from aniline, meta- and paranitraniline, $\alpha$ - and $\beta$-naphthylamine, benzidine, tolidine and dianisidine. They find that with the exception of the last three named, the decomposition is according to the law of unimolecular reactions. Benzidine, tolidine and dianisidine decompose at irregular rates and follow no simple law. Winodrado (Ztg. Untersuch. Nahr. u. Genussmittel, 1903, p. 589), from a study of the action of twenty-five dyes upon the digestion of egg albumen by pepsin, finds that all of the dyes used, either prevent or considerably diminish the action of the ferment. Perkin ( $J$. Soc. Chem. Ind., I903, p. 600) discusses the properties and constitution of certain phenolic coloring-matters occurring in the natural dyestuffs. Heermann (Faerber-Ztg., I903, p. II 7 ), from a study of the temperature influence upon the absorption of metallic mordants by silks, concludes that it is of minor importance, but at a low temperature there is a retardation in the absorption which may result in uneven mordanting. About $15^{\circ} \mathrm{C}$. or $20^{\circ} \mathrm{C}$. is the most favorable temperature. Hill (Proc. Chem. Soc., I9, I33 (I903)) has examined the coloring-matter from Butea frondosa. $A$ phlobaphene was obtained, and also a yellow gum, giving the reactions of fisetin. The coloring-matter, butein, $\mathrm{C}_{15} \mathrm{H}_{10} \mathrm{O}_{5}$, closely resembles benzylidine-anhydroglycogallol in its dyeing properties. Sandmeyer (Ztg. f. Farb. Text. Chem., I903, I29) has synthesized indigo from thiocarbanilide by heating together potassium cyanide 70 parts, basic lead carbonate 300 parts, thiocarbanilide 200 parts, water 200 parts, and spirits 500 parts, to a temperature of about $60^{\circ} \mathrm{C}$. The mixture is filtered and the solid residue extracted with ether or alcohol, yielding long, yellow prisms; by treatment with yellow ammonium sulphide the thio-oxaminediphenylamidine, $\left(\mathrm{C}_{6} \mathrm{H}_{5} . \mathrm{NH} . \mathrm{C}\left(. \mathrm{CNH}_{2}\right): \mathrm{S}\right): \mathrm{N}^{\mathrm{C}} \mathrm{C}_{6} \mathrm{H}_{5}$, is formed; by treating this with sulphuric acid, $\alpha$-isatinanilide,

$$
\mathrm{C}_{8} \mathrm{H}_{4} \cdot \mathrm{NH} . \mathrm{CO} . \mathrm{C}: \mathrm{N} . \mathrm{C}_{8} \mathrm{H}_{5}
$$

is produced, which, on reduction, gives indigo. Hurst ( $J$. Soc. Dyers and Colourists, 1903, p. I05) discusses titanium salts as mordants for silk. From a titanium tanno-oxalate solution, in three or four hours, silk takes up 2.3 to 4.2 per cent. of its weight; in 5 per cent. titanous chloride solution the absorption increases the weight of the silk about 3 per cent., after fixing in a solution of sodium phosphate; titanium-sodium sulphate is used in 5 per cent. solution and fixed with calcium acetate.

Bleaching and Dyeing.-Justin-Muller (Rev. Gen. des Mat. Col., 7, 72 (1903)) reports that the precipitation of sulphur on the surface of the bath, in dyeing sulphur colors, may be pre- 
vented by adding neutral or alkaline sodium sulphite to the bath when made up. Vorlander, from a study of the dyeing properties of azobenzenetrimethyl-ammonium hydroxide, which is a strong base, concludes that the dyeing properties of basic dyes, are not due to their basic nature, bue rather to the power of ammonium compounds and unsaturated bodies, to form additionproducts. Thus the dyeing of wool or silk by basic dyes depends on an addition reaction between the carboxyl groups of the fiber and the ammonium compounds; while the action of acidl dyes is due to addition reactions between radicals oi the dye and the amino compound of the wool (Ztschr. angea. Chem., 1903, pp. 840-842). Dobbin and White (J. Soc. Chem. Ind., I903, p. I3I), in a stuly. of the action of hypochlorites upon iron stains in linen bleaching, have shown that ferric hydroxicle decomposes hypochlorite solution very rapidly, with copious evolution of oxygen gas. 1 . sample of gas liberated was found to contain 96.7 per cent. oxygen and 3.3 per cent. nitrogen, the latter probably being dite to air dissolved in the hypochlorite solution. This indicates the treatment of stained goods with acicl, and aftcridards with hypochlorite, as the more rational method of removing such stains, but experiments made in the reverse orcler failed to show any evidence of over oxidation or tendering of the goods. Knecht (Ber. d. chem. Ges., 36, I66-I69, I 549-1555 (I903)) finds titanous chloricle is more powerful than stannous chloricle as a reducing agent; the reduction of ferric to ferrous salt has been made the basis of a quantitative method for determining iron and titanium; nitro bodies are reduced to amines; azo dyes are quantitatively reduced and may be determined thus volumetrically; indigo forms indigo white at once, but on further heating a yellow crystalline body results. Prussian blue on cotton is decolorized by the trichloride, but the color returns on washing or hanging in the air; cupric sulphate is reduced to the cuprous state, and even to metallic copper. Later the trichloride was applied to the volumetric quantitative determination of nitro and 1jitroso bodies. In a course of a long investigation of the influence of certain teagents on the strength and dyeing properties of cotton yarn, Hübner and Pope (J. Soc. Chem. Ind., I903, p. To) discovered that potassium iodide has, superficially, an action similar to caustic soda on cotton, and an effect much like mercerization is obtained. Barium iodide, barium mercuric iodide, and potassium mercuric iodide also have a mercerizing action. The authors also conclude that the twist is the controlling factor in the strength of yarns. Matos (Ibid., p. T95) discusses the use of sulphur colors in printing cotton goods; various formulae for printing pastes are included. The use of nickel plated print rolls is not regarded very favorably by this author. Tingle and Morrison (Ibid., p. 730) have determined the shrinkage (loss of weight) in 
wool when scoured; this ranges from 25 per cent. when washed with soap solution to 28.5 per cent. when extracted with ether. A second sample lost 27.6 per cent. in the soap liquor and 24.2 per cent. with ether, 27.9 per cent. with alcohol and 27.2 per cent. with petroleum ether. Suevern and Mach (Farber-Ztg., I4, 54) give distinguishing reactions for viscose silk by Stearn's and Bardy's processes; microscopic examination of the cross-section distinguishes these viscose silks from other artificial silks at once. Georgievics (Ztschr. angew. Chem., I6, 574 (I903)) doubts the solid solution theory of Witt and considers the process of dyeing one of absorption, depending upon the nature of the surface. The chemical combination theory is also doubted, since no molecular proportions exist between the fiber and dyestuff. In another article ( $Z$ tg. f. Farben. u. Textil-Chem., IgO3, p. 2I 5 ) the author holds that the precipitates obtained from silk and wool by Knecht (Ber.d. chem. Ges., 35, I022 (I902)) were caused by impurities extracted by the alcohol, thus casting doubt on his theory of the nature of dyeing. The theory of $\operatorname{Binz}$ and Schroeter that the various actions of dyes is explained by their chemical constitution is also doubted. In view of the above criticism, Knecht has repeated his former work (Ztschr. f. Textil w. Farben-Chem., 2, 310 (1903)) and confirms his earlier conclusions.

Sugar.-Zamaron (Bul. de l'Assoc. des Chim. de Sucre et de Dist.,21, 53 (1903)), Dupont (Ibid., p. 59) and Rembert (Ibid., 747962), all report favorable results from barium aluminate solution in purifying sugar beet juice. Barbet (Ibid., p. 37) comments upon the failure to utilize the residues and marcs from wine in France. Saare and Martens (Ztschr. Spiritusind., 40, 436 (1903)) have proposed a new method for determining the sizing power of starch. The principle of the method is measuring the force required to pull a standard disk of brass through a definite thickness of the cold, solidified starch paste. It was found that the stiffness was affected by the time the starch paste had been boiled. Patterson (J. Soc. Chem. Ind., I903, p. 608) has made a study of the carbonaceous matter of animal charcoal. It has long been known that such char must contain nitrogen for decolorizing, and the brown organic matter in the char was shown to be capable of decolorizing caramel, and was about sixteen times better than good charcoal; this organic matter is very finely divided, has a gelatinous texture, and when brought into contact with coloring-matter in the presence of water the action is much like that of gelatinous alumina in forming a lake. This organic matter is soluble in sulphuric acid, insoluble in hydrochloric acid, contains $9.2 \mathrm{I}$ per cent. nitrogen, and when purified and dried its analysis fixed the empirical formula $\mathrm{C}_{25} \mathrm{H}_{20} \mathrm{~N}_{4} \mathrm{O}_{6}$. In new 
charcoal there is probably very little elementary carbon, but this nitrogenous body forms the greater part of the char. With each revivification some of this organic matter is destroyed, and finally the char is entirely spent. Claassen ( $Z$ tschr. Verein. deutsch. Zuckerind., I903, p. 333), in studying the effects of repeated concentration on sugar solutions, found that with a molasses containing 20 per cent. water, when concentrated to 10.5 per cent. of water, the highest temperature reached was I2I. $7^{\circ} \mathrm{C}$.; but aiter six boilings the boiling-point went up to $127^{\circ} \mathrm{C}$, and the water content remained at I 3.25 per cent. Treating the molasses with lime and saturating with sulphurous acid and carbon dioxide had no effect on the boiling.

Fermentation.-Kleinke (Woch. f. Brau., 20, I26 (1903)), in an attempt to brew a pale beer in cast-iron vessels, found the wort discolored and giving a bad flavor; but when fined with isinglass and matured, the beer was satisfactory. But a dark beer, brewed in the same vessels and barrelled without finings, showed nothing abnormal till bottled with a little sugar; then it developed a flavor of ink. The author suggests that the isinglass precipitated the iron tamate derived from the hops, but in the dark beer the tannin remained and flavored the product. Brand (Ztschr. ges. Brau., 26, I33) traces the presence of iron in some beer samples, to the iron bung fittings of the cask. No iron is derived from the pitch in the cask. Smits (Ibid.. p. I69) examined the effect of lacquer, ordinary pitch and Brussels "Pechlack" as coating for fermenting vats. The pechlack led to intense fermentation at high temperature, yielding turbicl beer, with high attenuation and lack of "body." Paraffin as coating resulted in the same conditions. The smooth and continuotis coating was stated to be the cause of these results, and when some sterilized sand was added with the yeast, the fermentation became about normal. The author considers lacquer decidedly better than pitch for lining the vats. Beijerinck (Ztschr. $\dot{f}$. Spiritusind., 1902, pp. 50, 530, 54I, 550) reports upon the industrial use of lactic acid bacteria. There are two classes of "active" varieties, lactococcus and lacto bacillus. The former ferment milk at temperatures under $30^{\circ} \mathrm{C}$., are present in whey, ancl are used in cream ripening. The second group ferment milk at temperatures above $30^{\circ} \mathrm{C}$., and are used in koumiss and kefyr preparation, and in distillery mashes from grain. Parsons (This Journal, 24, II7O (I902)) tabulates the analyses of numerous malt liquors and discusses the question of the identification of a liquor as made by using even small quantities of malt. He considers a content of at least 0.04 per cent. phosphoric acid, and 0.25 per cent, albuminoids, as the minimum in genuine lager or ale. The preparation of dry malt extracts in Germany is discussed by Wolff (Woch. f. Brau., I9, 80I (IgO2)). The wort 
is evaporated in vacuo, and the resulting syrup dried down in a vacuum drying chamber at $60^{\circ} \mathrm{C}$. The dry crystalline mass is powdered. No caramel is produced in this method of drying. Delbrueck (Ibid., 20, 25) discusses the conditions and changes occurring in yeast reproduction. Jalowetz (Ibid., 22) considers the beneficial effect of lime added to the steep water, preliminary to the germination of barley. Windisch (Ibid., I9, 664) argues in favor of starting beer fermentations at higher temperatures, claiming that the flavor is not injured thereby, while if the yeast is not checked at the beginning, the process starts earlier and is more rapid, while wild yeasts are better suppressed. Magnanini and Venturi (Chem. Centrbl., 1903, I, I86) have studied the reactons between potassium bitartrate and calcium sulphate in plastered wines, and conclude that acid potassium sulphate is not formed to any large extent. Bredig (Ibid., 123) reviews the evidence bearing on the analogy between the action of inorganic catalytic agents and that of ferments. The action of enzymes is similar to that of other catalytic agents. Herzog ( $Z$ tschr. physiol. Chem., 37, I49-I60), by determining the reaction velocity of glucose and fructose, and the relation between the original concentration and the velocity constant, has demonstrated the catalytic nature of alcoholic fermentation, thus supporting Buchner's theory of the enzymatic character of fermentation. Buchner and Meisenheimer (Ber. d. chem. Ges., 36, 634 (1903)) found that the cells of certain bacteria could be killed by treatment with acetone, without materially injuring the enzymes they produce. The bacillus of lactic acid fermentation in sour distillery mashes was thus treated and the preparations dried. The dry mass, after rubbing up with sand and water, and digesting with cane sugar solution for four days, induced the lactic fermentation and the amount of acid obtained was larger when calcium carbonate was added during the fermentation. The bacteria of the acetic acid fermentation from a beer wort, when treated in the same way, produced acetic acid when digested in a 4 per cent. alcohol solution for three days. Calcium carbonate also proved useful in this case. Wiedling (Woch.f. Bran., I903, p. 82) has compared the process of short mashing at high temperature with the common method of three boilings; he finds no difference in the results, but concludes that the yield of extract is affected by the manner of running off the wort. In the short mash, after the decoction has boiled five minutes, the whole mash is heated to $70^{\circ} \mathrm{C}$, , and this heat kept up for one hour. This method does not extract any rank flavor from the husks and the beer has more body and good head. With much protein in the barley, the wort should be boiled at least two hours in the copper. Henneberg ( $Z$ tschr. Spiritusind., 26, gI (1903)) contributes an article on the morphology of certain distillery yeasts. Harden (Ber. d. chem. Ges., 36, 715 
(1903)) found that blood serum depresses the activity of the proteolytic enzyme in Buchner's yeast-cell juice; but egg albumen had no effect. This enzyme is supposed to destroy the zymase in fermentation of sugar and the addition of blood serum served to largely increase the evolution of carbon dioxide. Riviere (Bull. de 'Assoc. des Chim. de Sucr. et de Dist. I903, p. 1043) describes a method of recovering glycerine from distillery residues by osmosis with 95 per cent. alcohol. The alcoholic cxtract is distilled and a dilute glycerine obtained, which must be concentrated for crule glycerine. Stuckly (Woch. f. Braul, 20, 207 (I903)) used bleaching powder in the steep tanks for barley; this improved the germination and the growth was more regular, but the odor of the bleach was noticeable in the mash and wort, and the beer had an unpleasant odor and flavor. 'These results were essentially confirmed by Dvorak (Ibid., p. 245). Effront (Compt. rend., 136 , 1556 (1903)) finds that abietic acid arlded to a liquid containing a mixture of ferments assists the growth of that ferment present in largest quantity, and retards the srowth of the others. Ordinary colophony, freed from turpentine and volatile matter, acts like pure abietic acid, and its use is suggested in distilleries and breweries as a protective reagent against infection with undesirable ferments. Thomas (Ibid,, p. Iorj) finds formic acid produced in fermenting sugar with yeast, provided nitrogenous food of certain kinds be provicled; urea, acetamicle and salts of ammonium produced it. The author also finds formic acid in malt infusions to which yeast has not been ard. Meisenheimer (Ztschr. physiol. Chom., 1903. p. 523) shows that juice pressed from yeast cells may be concentrated by freczing in tall cylinclers, and then thawing the ice slowly and withont agration of the liquid; the top is nearly pure water, while the bottom portion has higher fermentation power than the miginal juice. Nathan (Woch.f. Brau., 20, 395 (I902)) fincis that the increased rapidity of fermentation in beer by aicration is lue to the agitation produced. Wiley (U.S. Dept. Agr., Bur. of Chom., Bull. No. 72,22$)$ has studied the composition of American wines. Iachman (Ibid., P. 25) describes the manufacture of wine in California.

Fine Chemicals. -The chemical hehavior of gutta-percha has been studied by Sir Wm. Ramser (J. Soc. Chem. Ind., rgor, p. I 367 ), Miss Harriette Chick and Frank Collingridge. No conclusions were reached as to the actual formula of gutta. but its oxiclation product, albane, is shown to contain thirty-four carbon atoms. The molecular weight of gutta is thought to lie ver: high. Walbaum (J. prakt. Chem., Ig03 pp. 235-250) has examined the essential oil of acacia flowers. From Acacia Caronit an oil was obtained which contained 40 to 50 per cent. engenol, 
8 per cent. methyl salicylate and considerable quantities of benzaldehyde, geraniol, benzyl alcohol, anisic aldehyde, eugenol methyl ester, and small quantities of several other substances. The oil from Acacia Farnesiana contained no eugenol, but otherwise was similar to the preceding oil. Vizes (Bull. Soc. Chim., I903, p. 896) reports upon the examination of the oil of turpentine. The normal adulterants are rosin and rosin oil, which may be present in consequence of the method of manufacture. The abnormal adulterants, added for fraudulent purposes, are chiefly petroleum oil and spirit, shale oil, benzene or carbon disulphide. Walbaum and Huethig (J. prakt. Chem., 67, 3I5 (I903)) have determined the constants of Neroli oil, of French origin; indol was not cletected with certainty; the odor is considered to be depenclent upon the presence of the methyl ester of anthranilic acid. Oil of Petitgraine was also examined. Bennett (Chem. and Druggist, 62, 59 I (1903)) discovered "acetine" (the acetic esters of glycerine) as an adulterant to the extent of 15 per cent. in peppermint oil. Walther (Chem. Ztg., 26, 344 (Ig03)) reports upon the valuation and testing of essential oils. For oil of anise, the solubility in alcohol, specific gravity, and solidifying-point are necessary. Oil of bergamot is valued upon its content of the esters of linalool and geraniol, which are determined by Koettstoerfer's method of saponification; the total amount of these esters should not be less than 32 per cent. The optical rotation is from $+8^{\circ}$ tu $-f 20^{\circ}$, and the sp. gr. 0.880 to 0.886 . The solution, in an equal volume of 90 per cent. alcohol, should be nearly clear and not alter on further dilution with alcohol. The residue on evaporation is 6 per cent. Oil of lavender should contain at least 30 per cent. of esters, but if freed from terpenes the percentage of esters is lower. Good French oil has sp. gr. 0.883 to 0.895 , dissolves in three volumes of 70 per cent. alcohol and has a rotation $-3^{\circ}$ to $-9^{\circ}$. Eugenol in onl of cloves is estimated as the difficultly soluble benzoic ester. Carvone in caraway and mint oils is best determined by titration according to the author's method, with hydroxylamine hydrochloride and sodium bicarbonate; in good oil the carvone is about 50 per cent. Oil of lemon is tested for its aldehyde content by converting it into oxime and titrating the excess of hydroxylamine with iodine. The normal amount of aldehyde is about 5 per cent. Parry and Bennett (Chem. and Druggist, 62, 88; 63, I 54 (1903)) report large quantities of citronella oil adulterated with about I5 per cent. of rosin spirit and peppermint oil adulterated with an oil distilled from African copaiba. Kremers (Pharm. J., 70, 6I (I903)) states that cedarwood oil, petroleum, resin and alcohol have been found as adulterants in cassia oil. Von Soden and Zeitschel (Ber. d. chem. Ges., $36,265-267$ (1903)) report the discovery of a new terpene alcohol in French oil of orange flowers, which is isomeric with and 
similar to geraniol. They name it nerol. Its sp. gr. is 0.880 , and it boils at $225^{\circ}-227^{\circ} \mathrm{C}$. It also occurs in other essential oils. Stolle ( $J$. Pharm. Chim., 27, 105 (1903)) finds that treatment of ether with sodium for several days, and filtering, is sufficient purification for anaesthetic purposes. Tanner (Pharm. J., I903, P. I34) has prepared a morphine acid tartrate, a hitherto undescribed salt. Lunge (Ztschr. angew. Chem., I6, I45), as reporter on indicators for the commission of the Fourth International Congress of Applied Chemistry, publishes that part of the report referring to alkalimetric indicators. Methyl orange is recommended for caustic and carbonated alkalies, and strong mineral acids and in a few other special cases. Phenolphthalein is recommended for organic acids; special indicators must be userl for borates, silicates, aluminates, etc. Fischer and Mering (Chem. Drug., 62, 620 (I903)) find that the alkyl substituted acetyl and malonyl ureas have strong hypnotic properties; veronal is a body of this class. Wijs (Ibid.. p. 620) finds that the iodine value of cod-liver oils rises as the specific gravity is higher. Hoffmeister (Ber. d. chem. Ges., 36, I047 (1903)) finds the wax extracted from flax by ether, benzene, etc., has a sp. gr. of 0.9083 at $15^{\circ} \mathrm{C}$ and melting-point $61.5^{\circ} \mathrm{C}$. It is partly soluble in alcohol and chloroform, but not in water; the saponification value is IOI.5I; Reichert-Meissl value, 9.27; Hehner value, 98.3I; iodine value, 9.6 ; unsaponifiable residue, 81.32 per cent. The last consists of a hard, yellowish brown body, with carbon $=83.9 \mathrm{I}$, and hyclrogen $=15.40$ per cent., showing it to be a paraffin resembling ceresin. The solid fatty acids contained palmitic and stearic acid; the liquid acids were oleï, linolic, linolenic and isolinolenic; it also contained phytosterol and ceryl alcohol. Hesse (Ber. d. chem. Ges., 36, I 459 (I903)) finds the essential oil of tuberose to consist of methyl anthranillate, benzyl benzoate and other derivatives of benzoic acid. In the oil extracted by infcuragc methyl silicylate was present, while the content of methyl anthranillate was about 5 per cent.; in the oil obtained by petroleum spirit extraction no methyl salicylate was found and only I.I3 per cent. of methyl anthranillate.

Fats and Oils.-Lewkowitsch ( $J$. Soc. Chem. Ind., 22, 67 ( 1903 ) gives an account of his studies on the hydrolysis of oils by dilute acids and notes upon fat-splitting enzymes. He states that dilute sulphuric acid appears to have no action on cotton seed, whale and rape oils, and on lard; dilute hydrochloric acid indicated a slight hydrolysis, so trials were made with concentrated acirl alone, and in the presence of some free fatty acid, with the hope of accelerating the saponification, but the results did not give encontragement to hope that a technical method along these lines cot1ld succeed; complete saponification requires a very long 
time. Trials on lard were also made with concentrated hydrochloric acid in the presence of catalytic substances, but without success. The enzyme lipase, obtained from pigs' livers, was tried on cottonseed oil, but no hydrolysis exceeding 3 per cent. resulted. The failure is supposed to be due to the lack of complete and permanent emulsion. Connstein, Hoyer and Wartenberg (Ber. $d$. chem. Ges., 35, 3988-4006 (I902); Connstein: Fifth Internat. Cong. Appl. Chem., Berlin, I903) have examined the conditions under which fats are decomposed by the lipolytic enzyme of castor beans, a reaction discovered by Green (Proc. Roy. Soc., 48, 370) and by Sigmund (Monatsh. f. Chem., II, 272). These experimenters find that a certain amount of free acid must be present for this hydrolysis to take place, and that water is essential to good yields of glycerine and fatty-acid; the most favorable strength of acid is put at $\mathrm{N} /$ Io to $\mathrm{N} / 3$; acetic acid, sulphuric acid, phosphoric acid and acid sulphates all give good results. A good emulsion is necessary for the best action of the enzyme and the temperature is best kept at about $40^{\circ} \mathrm{C}$. A higher temperature weakens the enzyme. It is proposed to use the method technically to hydrolyze fats, and then treat the separated fatty acid with alkali carbonate for soap. Cheapness and good color of the fatty acid and glycerine is claimed for the method. Braun and Behrendt (Ber. d. chem. Ges., I903, pp. Ig00-IgII) have compared the decomposing action of the enzymes from castor beans and jequirity seed (Abrus precatorious) upon linolin, carnauba wax and certain esters of organic acids, and found the jequirity seed had the stronger effect. Light is not essential to the decomposing action; small amounts of mercury, copper, or iron salts checked the action, while magnesium salts, alkalimetal salts and tungsten compounds had no effect. Zellner (Monatsh. f. Chem., I902, p. 937) has examined the oil expressed from the ripe berries of Sambucus racemosa. The oil contains a deep reddish coloring-matter, which animal charcoal removes in part. The oil is non-drying, has a sp. gr. of $0.917 \mathrm{I}$ at $15^{\circ} \mathrm{C}$., refractive index of 1.472 at $20^{\circ} \mathrm{C}$. (with sodium light); saponification value, I96.8; Reichert-Meissl value, I.8; acetyl value, I5.5; Hehner value, 95.0; iodine value, 89.5; with caustic soda a yellow soap was formed; nitric acid gives a green color, which bleaches later; sulphuric acid gives a green color, which changes to brown; the liquid fatty acids comprise about 79 per cent. of the total insoluble fatty acids; they were chiefly oleïc and linoleic acids. Dunlap and Shenk (This Journal, 25, 826-836 (1903)) have studied the oxidation of linseed oil, using benzene and ligroin solutions of a pure boiled oil containing lead and manganese as driers. The oxidation was brought about by aspirating air through the solutions. The results show that the oxidation was complete in about ten days, and the total weight of solid oxidized product was $8 \mathrm{I} .5$ 
grams (from Ioo grams of oil), while the residue from evaporating the ligroin in vacuo was 20 grams. In the solid oxidized products two colored layers were noted, a dark and a light one. On examining these separately, each weighed 60 grans; the dark product had an iodine value of 54.2 ; the other gave 26.7 and 28.5. The solution in benzene was much slower in oxidation, requiring a month, and only one solid product resulted, having an iodine value of 22.0 and 22.7. Hébert (Compt. rend., I36, 682) has continued his experiments on the action of metals, etc., on fatty acicls of heavy molectlar weight, and finds at high tentperatures that sodium, magnesium, iron, aluminum, tin and zinc give carbon dioxide, water and small quantities of hydrocarbons of the olefine group higher than $C_{1 i}$. Copper and silver seem to have no action. Gill and Tufts (This Journal, 25, 25 I (1903)) have found that the supposed cholesterol in corn oil is probably the same as sitosterol, found in wheat and rye by Burian (Monatsh. f. Chem., i897, p. 55I). A method of detectng corn oil in cottonseed oil is proposed by the authors, based upon the different silubilities in alcohol of the acetates of sitosterol and phytosterol, in consequence of which these may be separated by recrystallization and the melting-points determined. These authors (Ibid., p. 498), from an examination of the fatty alcohol found in olive oil of known purity, conclude that it is phytosterol and not cholesterol which occurs in that oil. Lewkowitsch ( $J$. Soc. Chem. Ind., I903, p. 592) points out a number of unsolved incustrial problems of the fat and oil industry. Coste and Shelbourn (Ibid., I903, p. 775) have examined the nature of neats' foot oil; several tables of results are given. The vellow color is supposed to be due to a pigment of the nature of lipochrome: the unsaponifiable matter is chiefly cholesterol; the presence of phytoster 21 would indicate adulteration with vegetable oils; the iodine absorption is high and indicates about 80 per cent. triolein; the solid acids are stearic and palmitic: the oil shonlel not show excessive rancidity from age; if nitrogenous and other organic matter is left in the oil, the fatty acids are liberated after a time; commercial samples are very liable to be found adulterated. This oil, when shaken with nitric acid (sp. gr. I.37), showed considerable divergence in the colors produced, and this test is rejected. Kebler and Pancoast (Proc. Am. Pharm. Assoc., 50, 363) have examined true bear fat, a semi-opaque oil in summer, but which solidifies at $9^{\circ} \mathrm{C}$. Its sp. gr. at $15^{\circ} \mathrm{C}$. is $0.9 \mathrm{r} 3$; saponification value, 203.4 ; acid value, 3.93 ; iodine value, 80.43 . These authors have also determined the constants of rattlesnake oil. Klimont (Monatsh. f. Chom., 24, 408 (Ig03)) finds Chinese vegetable tallow to contain a mixed glyceride oleo-dipalmitin, $\mathrm{C}_{3} \mathrm{H}_{5}\left(\mathrm{C}_{1.6} \mathrm{H}_{31} \mathrm{O}_{2}\right)_{2} \cdot \mathrm{C}_{18} \mathrm{H}_{33} \mathrm{O}_{2}$. Zay and Musciacco (Chem. Centrbl., I903, II, 223) have determined the constants of Chinese 
vegetable tallow. Garrett and Smith (Proc. Chem. Soc., I9, I64 (I903)) have examined the bases in Scotch shale oil; certain diand tri-methyl pyridines were purified, and their properties and reactions studied.

India Rubber.-Harries (Ber. d. chem. Ges., I902, pp. 44293 I; I903, p. I937), in a continuation of his previous work, has established the formula of his "nitrosite" c. (formed by treating caoutchouc with nitrous acid $)$ to be $\left(\mathrm{C}_{10} \mathrm{H}_{15} \mathrm{~N}_{3} \mathrm{O}_{7}\right)_{2}$. The molecular weight found is $56 \mathrm{I} .5$ (theoretical value, 578 ). It is now certain that only one substance is produced by the action of nitrous acid on Para caoutchouc, which is probably a derivative of diterpene. In a later article the author shows the same "nitrosite" may be obtained from other kinds of caoutchouc. He also proposes the use of the nitrosite process for technical analyses of rubber mixtures. Weber (Gummi Ztg., I903, p. 252) states that aliphatic alcohols precipitate rubber in inverse proportion to their molecular weights. In another article (Ibid., p. 296) he reports on the action of litharge in vulcanization. Litharge makes rubber brittle and hard if used in excess, but the action does not seem to be chemical, for solvents will extract the rubber constituents from the hardened mass. Polymerization is supposed to be caused. Other basic oxides, such as calcium, magnesium and zinc oxides, also cause hardening of rubber when heated in the presence of sulphur. The same author (India Rubber J., 24, 5 I 7 (I9O2) ) found about I 2 per cent. of paraffine wax, used as a protective coating on a piece of rubber thread from elastic web. Its purpose is to prevent the cutting action of the weft threads on the rubber when the web is in use. He also states (Ibid., I902, p. 565 ) that the plasticity of recovered rubber is dependent upon the presence of oils which are soluble in rubber solvents. Hence this material is unsuited for making coated goods, as the rubber soon becomes "crummy," owing to the loss of the oils by the action of the solvents in the "dough." He further discusses (Ibid., I903, p. I9) the coagulation of rubber latex, and takes issue with Leconte that mercuric chloride does not coagulate the latex of $L$. hendelotii. He also has noted that different alcohols coagulate rubber in quantities varying with their molecular weights. Further, the suggestion of Leconte that the formation of rubber in the trees may be due to oxydaze acting on the carbohydrates is doubted, since none of the latter have an iso-pentosan structure necessary to produce the carbon chain characteristic of rubber. Again, in Gummi Ztg., Ig03, p. 345, Weber suggests collecting the milk of the Hevea and bringing it to a central point to be separated by centrifugal machines, and then smoked, as a means of improving the quality of crude rubber. The deterioration of Congo rubber he considers due to albuminous substances present in it, and the blackening when exposed to sunlight may 
be caused by the action of oxydase on these albumins. Imperfect washing in working rubber causes the goods to be brittle when finished. The chemistry and analysis of rubber is considered by Weber (Gummi Ztg., i7, 20; ; Bir. d. chw wes, 36. 3103-3108 (1903)). He thinks it improbable that rubber, as such, exists in the latex, but that it is formed by polymerization from the oily liquid of the rubber milk. He has utilized the action of nitrogen peroxide on India rubber as a means for the determination of true rubber in both crude rubber and in manufactured articles. The gas, nitrogen tetroxide, is tried and passed into the solution of crude rubber in benzene. the flow of gas is stopped then the liquid becomes red; after standing an hour a yellow friable mass, corresponding to the formula $\mathrm{C}_{10} \mathrm{H}_{10} \mathrm{~N}_{2} \mathrm{O}_{4}$ is obtained, which is filtered from the benzene, dricel at $50^{\circ} \mathrm{C}$., and treated with acetone, in which it instantly dissolves, leaving a gray mul, consisting of the mineral matter and albunninous substances present; these are filtered out, washed with acetone, dried and weighed. The filtrate and washings are poured into eight volumes of water, which precipitates the yellow, flaky nitro-compound of pure rubber. This is filtered in a weighed filter, washed with warm water and dried at less than $90^{\circ} \mathrm{C}$. and weighed. This borly contains 59.65 per cent. pure rubber. For vulcanized rubher, the Henriques-Weber method of separating oils, paraffins, wax, resins and free sulphur by means of acetone is employed, followed by treatment of the residue with alcoholic soda; the sample is then washerl in hot water, dried, treated with nitrogen tetroxide in benzene, as in the case of crude rubber alone. Grimshaw. Tong anrl Barns (J. Soc. Chem. Ind., 22, 338 (1903)) outline their methor of analysis for vulcanized rubber, and show a table of rew11ts from numerous samples.

Tanning.-At the conference of the International Association of l.eather Trades Chemists. held at Leeds, Eng., last year, certain changes in the official methods of analysis of tanning materials were adopted. The hide powder used must contain not les thatn LI.5 per cent. nitrogen, calculated on the assumption of $\&$ per cent. moisture present; and the amount of soluble matter from the hide powder, as shown by a blank test with distilled water, must not exceed 5 milligrams per each $50 \mathrm{cc}$. of filtrate. The filtrate must show no turbidity with a gelatin-salt solution. In the filtration of tannin solution any suitable paper may be used, a correction being made for the tannin absorbed in the paper. Kaolin may also be used if needed, and a suitable correction applied for tannin absorbed. The determination of nontannins is to be made by the filter method, but the use of the chromed hide-powder method of the Association of Official Agricultural Chemists is permitted if so stated in the report. The 
solution from spent tans, if too weak by the official method of extraction, may be concentrated by boiling under reduced pressure, or in a flask whose neck is closed by a funnel. Proctor and Blockey (J. Soc. Chem. Ind., Ig03, p. 482) present data relating to the absorption of non-tanning substances by hidepowder, and its influence on tannin estimation. The tabulated results of some twenty-four analyses show that a serious error may result, which, however, is somewhat less by the "shake" method than by the filtration process. The superiority of chromed hide-powder for absorbing the tannin was also established, but it is admittedly very troublesome for occasional use, since it does not keep well when wet. Lepetit (Chemische Industrie, 26, 221 (1903)) found that sodium sulphites added to Quebracho extract, caused much of the sulphur to combine with the organic constituents, so that the addition of acids to the extract did not liberate sulphur dioxide; the sulphites had a modifying action on the tinctorial properties of the extract. Fahrion (Ztschr. angew. Chem., I6, 665 (I903)), from a study of the various tanning processes, concludes that leather is to be considered as a salt, in which the hide plays the part of either an acid or a base; there must, however, be some oxidation of the hide in the tanning process, if good leather is to be made. Lamb ( $J$. Soc. Dyers and Colourists, I903, p. 25I) finds that formic acid can be used in leather dyeing up to the maximum coloring effect, without danger of injuring the goods; it is better than sulphuric acid with certain dyes, but for removing iron stains the latter is more effective. Wood ( $J$. Soc. Chem. Ind., I903, p. I234) has reviewed the recent changes in the tanning industry; the use of titanium salts instead of chrome salts, and "formalin" has been taken up by some tanners, as also the Payne and Pullman indirect liming process, in which the hide is soaked in calcium chloride, and then passed into caustic soda, by which calcium hydroxide is produced among the fibers of the skin: but the hair is not loosened unless some bacterial action has begun in the preliminary soaks. Formic acid may also replace sulphuric acid to some extent in the tannery; extraction processes with naphtha are in use for removing grease from the skins. Koerner has published recent papers supporting the physical view of the tanning process, while Fahrion (see above) supports the chemical theory.

\section{REVIEW.}

High SCHOOL ChEMISTRY IN ITS RELATION TO THE WORK OF A COLLEGE CoURSE. By RUFUS P. WILI,IAMS. A paper read before the National Educational Association at its Boston Meeting and published in Science, Vol. $18, \mathrm{pp} .33^{\circ}-336$.

Inquiries sent by the author of the paper to twenty-three col- 